\title{
Targeting Wnt Signaling in Endometrial Cancer
}

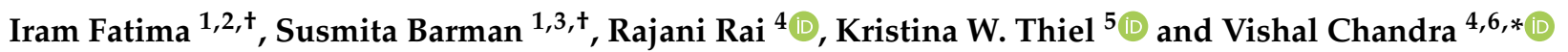 \\ 1 Department of Biochemistry and Molecular Biology, University of Nebraska Medical Center, \\ Omaha, NE 68198, USA; irambiotech08@gmail.com (I.F.); susmita.barman1987@gmail.com (S.B.) \\ 2 Division of Endocrinology, Central Drug Research Institute, Uttar Pradesh, Lucknow 226031, India \\ 3 Department of Biochemistry, CSIR-Central Food Technological Research Institute, Mysore, \\ Karnataka 570020, India \\ 4 Stephenson Cancer Center, University of Oklahoma Health Sciences Center, Oklahoma City, OK 73104, USA; \\ rrai@ouhsc.edu \\ 5 Department of Obstetrics and Gynecology and the Holden Comprehensive Cancer Center, University of Iowa, \\ Iowa City, IA 52242, USA; kristina-thiel@uiowa.edu \\ 6 Division of Gynecologic Oncology, Department of Obstetrics and Gynecology, College of Medicine, \\ University of Oklahoma Health Sciences Center, Oklahoma City, OK 73104, USA \\ * Correspondence: vchandra@ouhsc.edu \\ + Co-first authors.
}

check for

updates

Citation: Fatima, I.; Barman, S.; Rai, R.; Thiel, K.W.; Chandra, V. Targeting Wnt Signaling in Endometrial Cancer. Cancers 2021, 13, 2351. https:// doi.org/10.3390/cancers13102351

Academic Editors: Michael Kahn, Kimberly K. Leslie, David G. Mutch, Doris M. Benbrook and Kristina W. Thiel

Received: 1 April 2021

Accepted: 8 May 2021

Published: 13 May 2021

Publisher's Note: MDPI stays neutral with regard to jurisdictional claims in published maps and institutional affiliations.

Copyright: (c) 2021 by the authors. Licensee MDPI, Basel, Switzerland. This article is an open access article distributed under the terms and conditions of the Creative Commons Attribution (CC BY) license (https:// creativecommons.org/licenses/by/ $4.0 /)$.
Simple Summary: Wnt has diverse regulatory roles at multiple cellular levels and numerous targeting points, and aberrant Wnt signaling has crucial roles in carcinogenesis, metastasis, cancer recurrence, and chemotherapy resistance; based on these facts, Wnt represents an appealing therapeutic target for cancer treatment. Although preclinical data supports a role for the Wnt signaling pathway in uterine carcinogenesis, this area remains understudied. In this review, we identify the functions of several oncogenes of the Wnt/ $\beta$-catenin signaling pathway in tumorigenesis and address the translation approach with potent Wnt inhibitors that have already been established or are being investigated to target key components of the pathway. Further research is likely to expand the potential for both biomarker and cancer drug development. There is a scarcity of treatment choices for advanced and recurrent endometrial cancer; investigating the sophisticated connections of Wnt signaling networks in endometrial cancer could address the unmet need for new therapeutic targets.

Abstract: This review presents new findings on Wnt signaling in endometrial carcinoma and implications for possible future treatments. The Wnt proteins are essential mediators in cell signaling during vertebrate embryo development. Recent biochemical and genetic studies have provided significant insight into Wnt signaling, in particular in cell cycle regulation, inflammation, and cancer. The role of Wnt signaling is well established in gastrointestinal and breast cancers, but its function in gynecologic cancers, especially in endometrial cancers, has not been well elucidated. Development of a subset of endometrial carcinomas has been attributed to activation of the APC/ $\beta$-catenin signaling pathway (due to $\beta$-catenin mutations) and downregulation of Wnt antagonists by epigenetic silencing. The Wnt pathway also appears to be linked to estrogen and progesterone, and new findings implicate it in mTOR and Hedgehog signaling. Therapeutic interference of Wnt signaling remains a significant challenge. Herein, we discuss the Wnt-activating mechanisms in endometrial cancer and review the current advances and challenges in drug discovery.

Keywords: endometrial cancer; Wnt signaling; $\beta$-catenin; mutations; targeted therapy

\section{Introduction}

The human endometrium is a proliferative, angiogenic, and dynamically regenerated normal tissue that is the anatomic prerequisite for pregnancy. Stem/progenitor cells (epithelial, mesenchymal, endothelial) likely contribute to both the rapid endometrial cyclic growth and regeneration of 4-14 mm of mucosa per cycle during a woman's reproductive 
lifespan and endometrial regeneration/repair postpartum. During the reproductive life of women, the human endometrium undergoes dynamic cyclical changes with $\sim 400$ cycles of regeneration, differentiation, and shedding (menstruation). These cycles are regulated by many signaling pathways but primarily by estrogen and progesterone hormone signals [1]. Estrogen is a classical proliferative signal in the endometrium whereas progesterone counteracts the effects of estrogen to promote cellular differentiation. This dynamic balance between the pro-growth and pro-differentiation effects of estrogen and progesterone, respectively, is essential to prevent abnormal endometrial proliferation. Indeed, several gynecological diseases are associated with abnormal endometrial proliferation, including endometriosis, adenomyosis, endometrial hyperplasia, and endometrial cancer [2,3]. Tumors that develop from the single layer of epithelial cells that line the endometrium and form the endometrial glands are classified as endometrial carcinomas $(98 \%$ of endometrial tumors) while tumors that develop in the muscle layer (myometrium) or stromal tissue (supporting connective tissue) within the muscle layer are called sarcomas (2\%) [4].

Endometrial cancer is the sixth most common gynecologic malignancy of the female reproductive organs and, while rates vary by geographic region, overall, it afflicts approximately 27.8 per 100,000 women worldwide annually [5]. In the US alone, over 65,000 women were diagnosed with endometrial cancer in 2020 with 12,500 deaths. Endometrial cancer is one of only two cancers for which both incidence and mortality are on the rise as compared to 40 years ago [6], and this increase can be attributed, in part, to the obesity epidemic [7]. Endometrial cancer incidence is particularly high in black females in the US with a disparately high mortality compared to other racial and ethnic groups [8].

Genetic alterations as well as various cell-signaling pathways have been implicated in endometrial cancer development and progression. These pathways include Wnt/ $\beta$-catenin signaling cascades (together with APC/ $\beta$-catenin signaling), the PI3K/AKT/mTOR signaling pathway, the MAPK/ERK pathway, the ErbB signaling pathway, the VEGF/VEGFR ligand-receptor signaling pathway, and the p53-P16INK4a signaling pathway. Endometrial tumor tissues have been shown to contain mutations in these signaling pathways, which are generally regarded as primary drivers of carcinogenesis [9]. A better understanding of these signaling transduction pathways as well as cross-connections between them is necessary in order to understand the mechanisms of action of existing targeted therapy drugs and to discover new therapeutic applications $[10,11]$.

The Wnt/ $\beta$-catenin signaling pathway is an extremely conserved pathway that is involved in a variety of cellular processes in the female genital system, including development, cell proliferation, cell survival, adhesion, and motility as well as the regulation of the menstrual cycle. In addition to its crucial role in tissue homeostasis, aberrant Wnt signaling plays a significant role in many diseases from cancer to metabolic disorders [12-17]. During the reproductive life in the endometrium, Wnt $/ \beta$-catenin signaling is regulated by estrogen and progesterone hormones. In the proliferative phase of the menstrual cycle, estrogen stimulates Wnt $/ \beta$-catenin signaling and enhances the nuclear accumulation of $\beta$-catenin. However, later, during the secretary phase, progesterone counterbalances estrogen-induced proliferation by inhibition of Wnt/ $\beta$-catenin signaling [18-20]. Aberrant regulation of the Wnt signaling pathway in the endometrium results in endometrial hyperplasia, which may proceed to endometrial cancer [21-23].

Early studies into the role of Wnt signaling in endometrial cancers mainly focused on identifying $\beta$-catenin gene mutations. However, mutation of APC (Adenomatous polyposis coli) or CTNNB1 (the gene that encodes $\beta$-catenin) is rare in endometrial cancer, indicating that other mechanisms are responsible for the aberrant activation of $\beta$-catenin [24-27]. Moreover, nuclear $\beta$-catenin staining is prominent in the early onset of endometrial cancer, endometrial hyperplasia, and well-differentiated endometrioid carcinomas [28,29]. Using the Cancer Genome Atlas (TCGA) database, we observed increased expression of $\beta$-catenin in human endometrial cancer patients (Figure 1A,B). Interestingly, these findings were more common in the endometrioid histologic type of endometrial cancers than in 
nonendometrioid endometrial cancers. Similarly, multiple studies show that inhibition of several negative regulators of the Wnt pathway (by epigenetic silencing), such as members of the soluble Frizzled protein (SFRP) and Dickkopf (DKK) families, may contribute to development and progression of endometrial cancer [30-40].

A

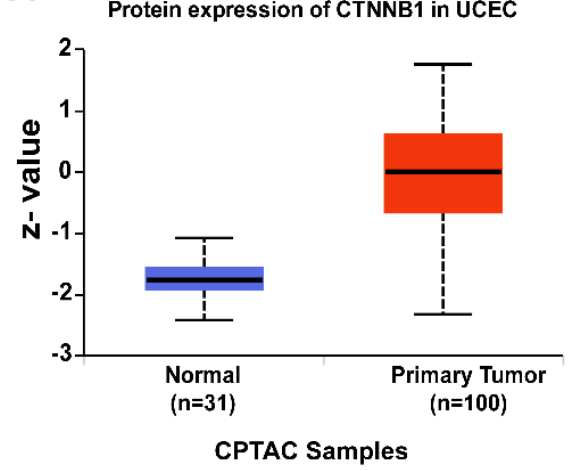

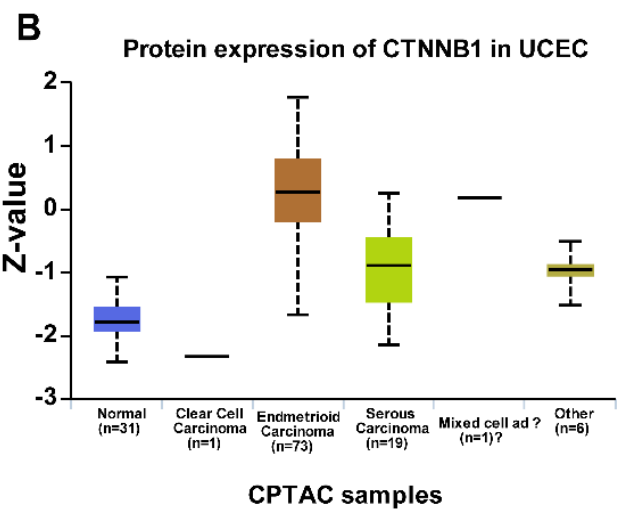

Figure 1. CTNNB1 proteomic expression profile in normal endometrium tissue vs. uterine corpus endometrial carcinoma (UCES, (A)), and across different histological grades (B).

Unlike for other cancers, the mechanism of Wnt signaling participation in endometrial cancer has not been elucidated and is not limited to the involvement of $\beta$-catenin and APC mutations. In this review, we present an overview of the Wnt signaling pathway and its activating mechanisms in endometrial cancer. We will address the common Wnt pathway-associated mutations identified in endometrial cancer and will further review the current therapeutic options targeting Wnt signaling considering both their potential and their limitations.

\section{Wnt Signaling}

The Wnt signaling pathway is evolutionarily highly conserved and is a crucial cascade regulating development and stemness. Wnt signaling is also firmly associated with several cancers. This signaling network can be divided into two modes based on the role of $\beta$-catenin: the $\beta$-catenin-dependent pathway is called "canonical Wnt/ $\beta$-catenin signaling" and the $\beta$-catenin-independent pathway is called the "noncanonical pathway." The noncanonical Wnt / $\beta$-catenin pathway can be further subdivided into the planar cell polarity (PCP) pathway and the Wnt/Ca2+ pathway [41-43] (Figure 2).

In both the canonical and noncanonical pathways, signaling is initiated by binding of Wnt ligands to the extracellular cysteine-rich domain (CRD) at the amino terminus of Frizzled receptors (Fzd) and a number of recently linked coreceptors, including receptor tyrosine kinase-like orphan receptor 1 (ROR1), receptor tyrosine kinase-like orphan receptor 2 (ROR2), and receptor-like tyrosine kinase (Ryk). This ligand-receptor interaction activates canonical WNT/ $\beta$-catenin and noncanonical WNT/PCP and WNT/Ca2+ signaling pathways. This mechanism is interfered with by several inhibitors and gatekeeper molecules, including the families of SFRPs and DKKs [21,44,45].

The canonical Wnt/ $\beta$-catenin pathway is activated by binding of Wnt to a transmembrane receptor complex that is formed from the seven-pass transmembrane Fzd and the co-receptor low-density lipoprotein receptor-related protein 5 or 6 (LRP5/6); binding is enhanced by the R-spondin/Lgr interaction. This Wnt-Fzd-LRP6 complex recruits scaffolding protein Dishevelled (Dvl), which leads to the phosphorylation of LRP6 and recruitment of the Axin complex to the receptors. This signaling cascade hinders Axinmediated $\beta$-catenin phosphorylation and subsequently stabilization of $\beta$-catenin. Liberated $\beta$-catenin then accumulates and translocates to the nucleus where it binds to $T$ cell factor and Lymphoid enhancer-binding factor 1 (TCF/LEF) and promotes the transcription of Wnt target genes, such as JUN, c-Myc, CCND1(Cyclin D1), and AXIN2 among others [46]. 


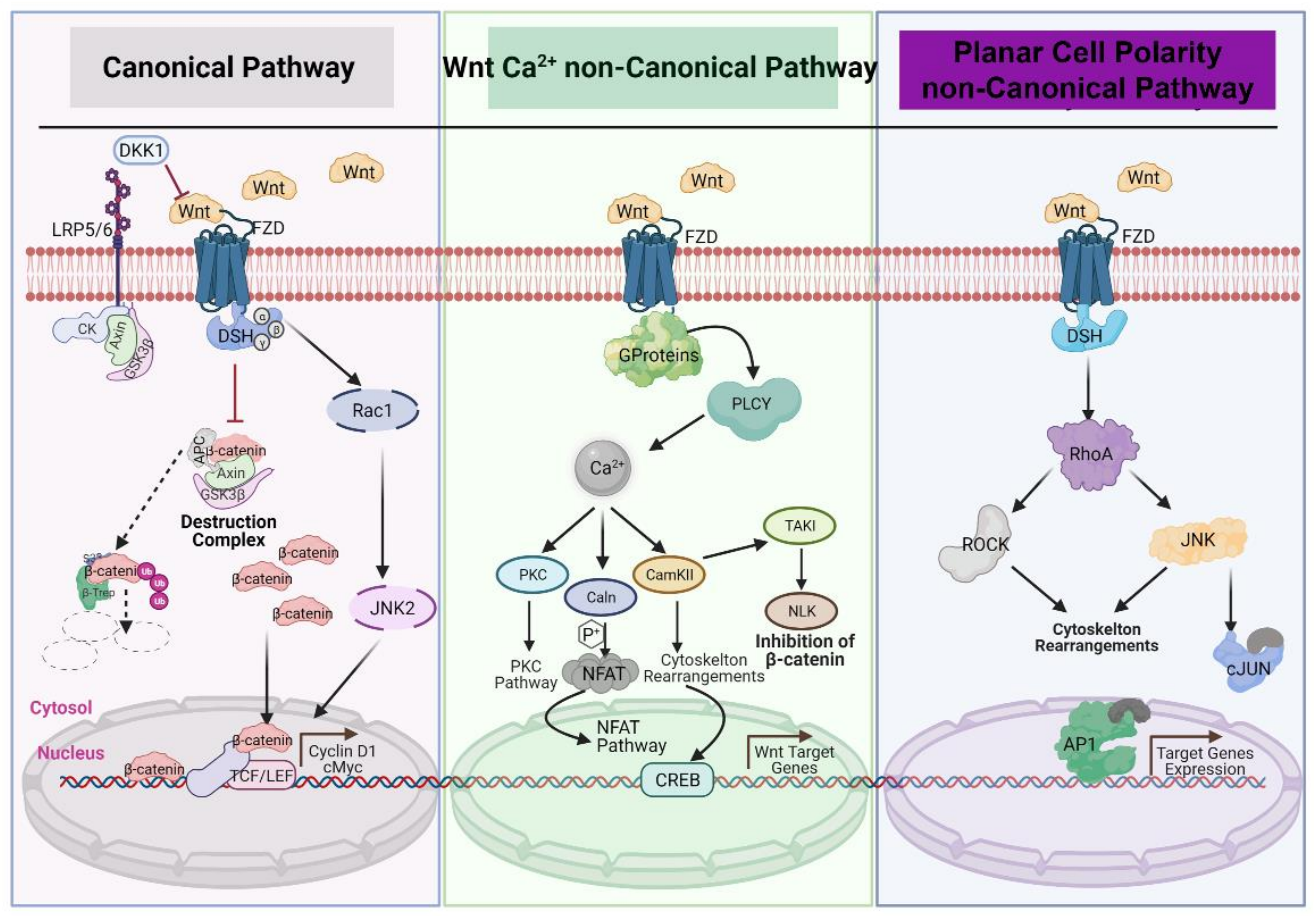

Figure 2. Schematic representation of Wnt signaling.

As mentioned above, the $\beta$-catenin-independent or noncanonical pathway can be further divided into two different branches, the planar cell polarity (PCP) pathway and the Wnt/Ca2+ pathway, both of which are activated by Wnt. The PCP pathway regulates cell motility and polarity through the activation of small GTPases, RhoA, Rac, and the c-Jun N-terminal kinase (JNK). The PCP pathway can be demonstrated by Wnt-Fzd interaction; however, receptor tyrosine kinase-like orphan receptors (RORs) like ROR1, ROR2, and receptor tyrosine kinase (Ryk) can also serve as Wnt receptors to activate $\beta$-cateninindependent pathways [47-50]). The Wnt/Ca2+pathway is activated upon Wnt ligation and leads to an increase in intracellular $\mathrm{Ca} 2+$ levels. This signaling comprises the activation of protein kinase $\mathrm{C}(\mathrm{PKC})$ and $\mathrm{Ca} 2+/$ calmodulin-dependent protein kinase II (CAMKII) through the mobilization of DVL and Phospholipase C (PLC) and the subsequent increase in intracellular calcium $(\mathrm{Ca} 2+)$ release from the endoplasmic reticulum (ER). The Wnt/Ca2+ pathway also signals through protein phosphatase calcineurin (Caln), stimulating the transcription factor nuclear factor of activated T cells (NFAT) $[42,43,46]$.

Wnt/ $\beta$-catenin pathway activation is a pivotal regulator of epithelial-mesenchymal transition (EMT) [51-53]. Wnt signaling is associated with increased expression of Snail, Slug and Twist, which control downregulation of the adherens junction protein epithelial (E)-cadherin and upregulation of mesenchymal specific marker neuronal (N)-cadherin during EMT, promoting cell migration. During early research, EMT was first identified in the setting of normal cell differentiation but is now recognized as a key factor in many different types of cancers, including endometrial cancer [51,54].

\section{Aberrations in Wnt Signaling in Cancer}

The role of aberrant Wnt signaling in cancer was first discovered during tumor induction in a mouse model following proviral integration at the WNT1 locus $[55,56]$. In recent decades, aberrant activation of Wnt signaling has also been documented in the proliferation, survival, and ability to metastasize in various cancer cell types. Continuous activation of Wnt signaling can be accomplished through either mutational or non-mutational alterations [12].

It is very well reported that aberrant activation of the canonical $\mathrm{Wnt} / \beta$-catenin signaling pathway is associated with the development of colorectal cancer through mutations in 
the APC and CTNNB1 ( $\beta$-catenin) genes that lead to hyperactivation of the pathway. Mutations of $\beta$-catenin that result in Wnt signaling dysfunction have frequently been observed in many other cancers, including endometrial cancer, ovarian cancer, medulloblastoma, hepatocellular carcinoma, and Wilms' tumor, with many studies supporting the idea that elevated $\beta$-catenin levels are associated with poor prognosis [12,57].

Furthermore, $\beta$-catenin is not the only important component of the Wnt signaling network. Several studies have been published in the last decade that correlate changes in Wnt ligands, receptors, gatekeepers, and downstream effector molecules to almost every type of human tumor. Dysregulation of both canonical and noncanonical Wnt signaling has been shown in numerous cancers $[16,22,37,54,58-63]$. Table 1 lists reports of Wnt pathway alterations in numerous tumor types.

Table 1. Alterations of major component of Wnt signaling pathway in Various Tumor Types.

\begin{tabular}{|c|c|c|c|c|}
\hline S. No & Type of Cancer & Mutation(s) & $\%$ Mutated & Reference(s) \\
\hline \multirow{5}{*}{1} & \multirow{5}{*}{$\begin{array}{c}\text { Colorectal } \\
\text { adenocarcinoma }\end{array}$} & APC & $60 \%$ & \multirow{5}{*}{ [64-68] } \\
\hline & & TCF7L2 & $7.70 \%$ & \\
\hline & & AMER1 & $10 \%$ & \\
\hline & & AXIN1 & $11 \%$ & \\
\hline & & CTNNB1 & $6.50 \%$ & \\
\hline 2 & Endometrial carcinoma & CTNNB1 & $19-30 \%$ & {$[26,69,70]$} \\
\hline 3 & Cervical carcinoma & WIF1 & $60 \%$ & [71] \\
\hline \multirow{2}{*}{4} & & CTNNB1 & 6.4 & \multirow{2}{*}[54,72,73]{} \\
\hline & Ovarian carcinoma & APC & $29 \%$ & \\
\hline \multirow{3}{*}{5} & Prostatic & CTNNB1 & $5 \%$ & \multirow[b]{2}{*}{ [74-76] } \\
\hline & $\begin{array}{l}\text { adeno } \\
\text { carcinoma }\end{array}$ & $\begin{array}{l}\text { TMPRSS2-ERG gene } \\
\text { fusion }\end{array}$ & $55 \%$ & \\
\hline & & WTX & $32 \%$ & \multirow{3}{*}{ [77] } \\
\hline \multirow[t]{3}{*}{6} & Wilms tumor & CTNNB1 & $15 \%$ & \\
\hline & & WT1 & $12 \%$ & \\
\hline & & APC & & \multirow[b]{2}{*}[58,60]{} \\
\hline 7 & Breast carcinoma & $\begin{array}{l}\text { Aberrant mRNA } \\
\text { splicing of LRP5 }\end{array}$ & 2.2 & \\
\hline \multirow{3}{*}{8} & Hepatocellular & CTNNB1 & $9.60 \%$ & \multirow{3}{*}{ [78-81] } \\
\hline & carcinoma & AXIN1 & 8.6 & \\
\hline & & APC & $80 \%$ & \\
\hline \multirow{3}{*}{9} & Donochor d & APC & 4.8 & \multirow{3}{*}{ [82-86] } \\
\hline & Pancreas ductal & CTNNB1 & 1.6 & \\
\hline & Carcinoma & RNF43 & 1.5 & \\
\hline
\end{tabular}

\section{Endometrial Cancer and Wnt Signaling}

\subsection{General Characteristics of Endometrial Cancer}

Endometrial cancer is the most common gynecologic malignancy found in women worldwide and it is the second leading cause of gynecologic cancer death in the United States [87]; for 2021, the American Cancer Society predicts 66,570 new cases and 12,940 deaths [5]. Endometrial cancer rates have been steadily increasing in recent years. Although Caucasian women are slightly more likely to develop this disease than African American women, African American women are more likely to die from it [88]. Endometrial carcinoma mainly affects postmenopausal women aged 56 to $66[89,90]$.

Increasing age, long-term use of unopposed hormone therapy, a history of nulliparity or infertility, irregular menstrual cycles, polycystic ovarian syndrome, obesity, diabetes mellitus, and hypertension are all risk factors for endometrial carcinoma [91-98]. In the United States, the five-year survival rate (at all stages) is estimated to be greater than $80 \%$ [6]. Patients with endometrial cancer have irregular endometrial bleeding, which frequently results in diagnosis at an early stage/grade in most cases. However, there are still many obstacles to overcome in the clinical treatment of endometrial cancer, particularly for patients diagnosed at a late stage or with a more aggressive histologic subtype. 
The majority of endometrial carcinomas are produced from endometrial glands (adenocarcinomas), while the remainder are derived from the supporting stroma (sarcomas) (Figure 3). Endometrial carcinomas are classically grouped into classes based on their cause, clinical characteristics (histologic subtype), and pathogenesis [99,100]. Endometrioid endometrial carcinomas have a hyper-estrogenic condition, are typically diagnosed at a low grade, are minimally intrusive into the underlying uterine wall (myometrium) and have a better prognosis. They have estrogen and progesterone receptors and are usually receptive to progesterone therapy. These carcinomas most commonly occur before and around the time of menopause and account for roughly $80 \%$ of endometrial cancers. In the United States, endometrioid endometrial cancers mainly occur in white women, mostly in those with a background of endometrial hyperplasia. Fortunately, with surgical, hormone, and/or chemotherapy treatments, endometrioid endometrial carcinomas have an approximately $85 \%$ overall 5-year survival rate [100,101].

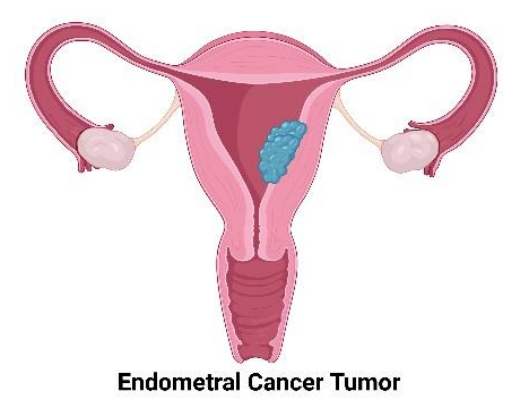

Figure 3. Endometrial cancer begins in the layer of cells that form the inner lining of the uterus (endometrium).

The second most common type of endometrial cancer is the serous subtype. These tumors are generally diagnosed at a high grade, are poorly differentiated with deep invasion into the underlying uterine wall (myometrium), are very aggressive, and have poor outcomes. They generally do not express the receptors for estrogen or progesterone and are not responsive to hormonal treatment. In the United States, serous endometrial cancers are more common in African American women. The 5-year survival rate for serous cancers is $53 \%[89,102]$. Another less common subtype of carcinoma of the endometrial lining is clear cell carcinoma, representing about $6 \%$ of all endometrial cancers and with a 5-year survival rate of $\sim 62 \%[100,101,103,104]$.

Understanding of the molecular profile of tumors may be more informative in terms of guiding treatment for individual endometrial tumors than segregation into histologic subtypes. The most comprehensive molecular study of endometrial cancer to date has been The Cancer Genome Atlas (TCGA) project, which revealed key molecular pathways and mutations associated with endometrial cancers; endometrioid subtypes most frequently had mutations of PTEN (a protein and lipid phosphatase), CTNNB1 ( $\beta$-catenin), PIK3CA, and KRAS, along with microsatellite instability and POLE mutations (Table 2) whereas serous endometrial carcinomas are characterized by genetic alterations in the tumor suppressor TP53, HER2/neu, p16, and E-cadherin [105-108]. 
Table 2. Molecular features of endometrial carcinoma: endometrioid and serous endometrial carcinomas.

\begin{tabular}{ccc}
\hline Molecular Markers & $\begin{array}{c}\text { Endometrioid } \\
\text { Endometrial Cancer }\end{array}$ & $\begin{array}{c}\text { Serous } \\
\text { Endometrial Cancer }\end{array}$ \\
\hline Microsatellite instability & $30 \%$ & $0-5 \%$ \\
DNA mismatch p16 & $10 \%$ & $45 \%$ \\
p53 mutation & $10 \%$ & $90 \%$ \\
KRAS mutation & $20-40 \%$ & $0-5 \%$ \\
ER/PR expression & $70-80 \%$ & $5 \%$ \\
Her-2 amplifica- & $15-20 \%$ & $18-45 \%$ \\
tion/overexpression & $40-50 \%$ & $10 \%$ \\
PTEN mutation & $14-44 \%$ & $0-5 \%$ \\
B-catenin mutation & $0-5 \%$ & $30 \%$ \\
CCNE1 amplification & $40 \%$ & $15 \%$ \\
PIK3CA mutation & & \\
\hline
\end{tabular}

\subsection{Wnt Signaling Abbereations in Endometrial Cancer}

Abnormal Wnt/ $\beta$-catenin signaling plays an important role in endometrial cancer onset. Around $40 \%$ of endometrial cancers (mostly endometrioid histology) show abnormalities in the Wnt signaling pathway. Activation of the Wnt signaling pathway via alteration of the APC, Axin, CTNBB1, Wnt ligands, Wnt inhibitors Dickkopf3 (DKK3) and Dickkopf1 (DKK1), or the secreted Frizzled-related proteins may be a key driving event in the development of endometrial cancer. Nuclear accumulation of $\beta$-catenin (e.g., 13-69\% of cases of endometrioid endometrial carcinoma) is the predominant alteration found in endometrioid tumors, but only a few studies have examined the role of Wnt signaling in its etiology $[27,109,110]$.

Some studies showed that during the proliferative phase of the menstrual cycle $\beta$ catenin is mainly localized in the nucleus whereas during the secretory phase $\beta$-catenin translocated from the nucleus to the cytoplasm and cell membrane [28]. Estradiol induces Wnt4, Wnt5A, and Wnt7A ligands as well as FZD-2 receptor expression, subsequent stabilization of $\beta$-catenin in the cytoplasm, and the presence of active $\beta$-catenin in the nucleus $[111,112]$. However, progesterone can act as a profound inhibitor of Wnt $/ \beta$-catenin signaling $[19,113]$. This may be due to the induction of DKK1 and FOXO1, which are important Wnt inhibitors. Studies by Wang et al. also showed that progesterone efficiently inhibits Wnt signaling in Ishikawa endometrial cancer cell lines [19].

Information on the importance of Wnt ligands in endometrial adenocarcinoma is increasing and it is likely that Wnt alteration plays a role in carcinogenesis. Bui et al. documented that Wnt4 mRNA is higher in normal endometrium than endometrial carcinoma; WNT2, WNT3, and WNT5A mRNA levels are similarly higher in normal endometrium than in endometrial carcinoma. This study suggests that down-regulation of WNT4, WNT2, WNT3, and WNT5A might be important in the development of endometrial cancer [102,114]. However, in 2014 Liu et al. reported that Wnt pathway components, such as Frizzled-10, TCF7, and LEF1 along with WNT5A, were overexpressed in $\beta$ catenin-mutated tumors in a validation study that compared the TCGA dataset to a broad independent cohort [115] (Figure 4).

Much of the research to date has focused on WNT7 gene expression. The expression of $W N T 7 A$ and $W N T 7 B$ genes is high in endometrial carcinoma cell lines but not in normal primary endometrial cultures $[32,116,117]$. In vivo, expression of both $W N T 7 A$ and $W N T 7 B$ can be detected in normal human endometrial tissues and human endometrial tumors. This discrepancy is likely due to the artificial environment and regulatory signals that control WNT7A and WNT7B expression [114]. In one clinical study of endometrial carcinoma, the expression of WNT7A gene was absent or reduced and was negatively linked with FIGO stage, grade, lymph node metastasis, depth of myometrial invasion, and peritoneal cytology in approximately $60 \%$ of patients [116]. In a large-scale population study of 244 endometrioid endometrial cancer patients, the WNT7A gene was overexpressed in most cases of endometrial cancer [117]. It is important to note, however, that the lack of 
expression of WNT7A positively correlated with overall survival and disease-free survival in endometrial cancer patients $[117,118]$, suggesting that overexpression of $W N T 7 A$ plays a pathogenic role.

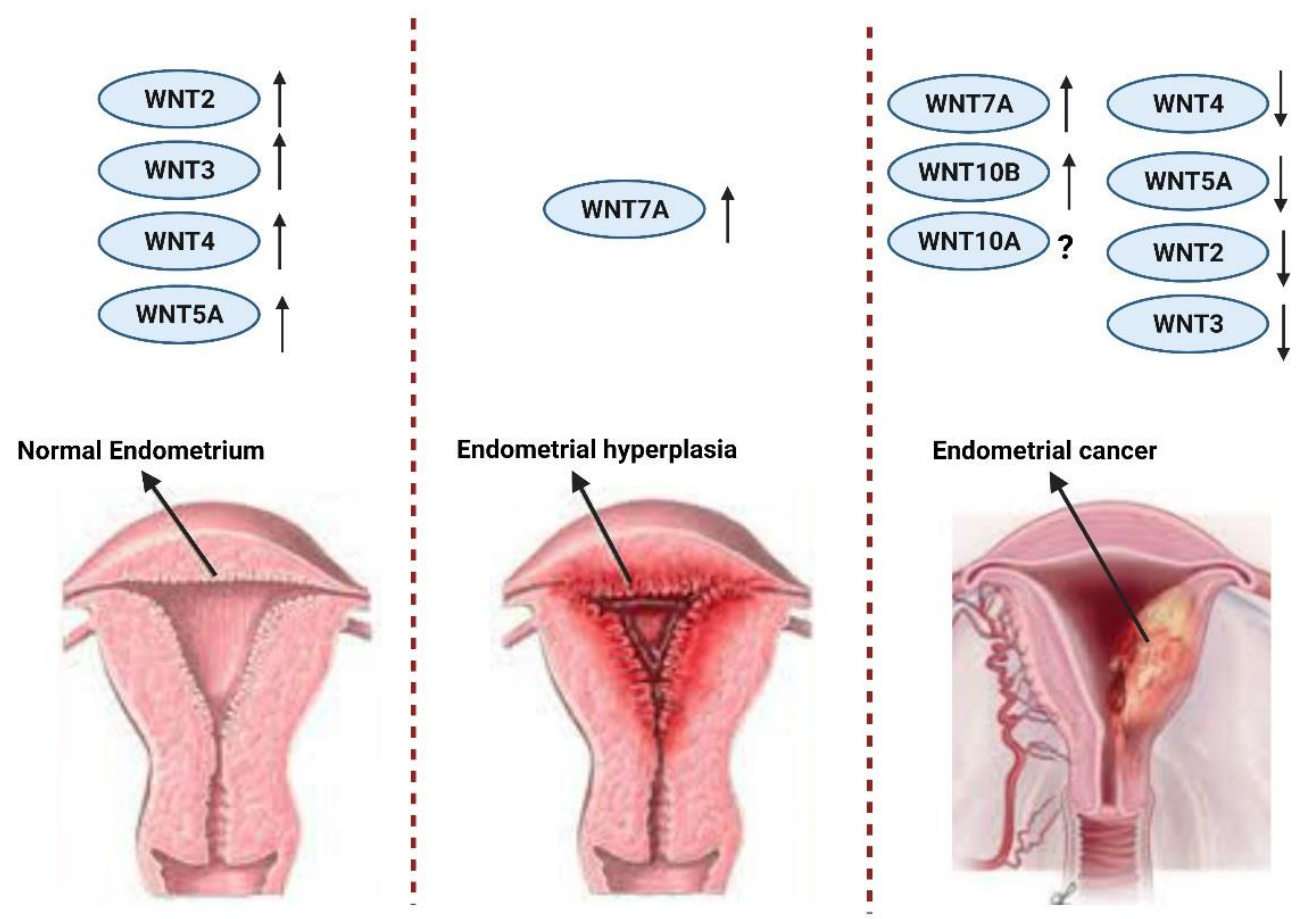

Figure 4. Expression of Wnt ligands in normal endometrium, hyperplasia, and endometrial cancer.

In addition to WNT7A, the expression of WNT10A and WNT10B ligands has been associated with estrogen-related carcinogenesis of endometrial cancer. Wnt10b protein expression is significantly higher in endometrial cancer tissue in comparison to hyperplastic endometrium and normal endometrium [119]. Moreover, the expression of Wnt10b correlates with the histological type of cancer, cell maturity, FIGO stage, and lymphatic metastasis. Elevated Wnt10b protein expression is associated with a better prognosis in endometrial patients. Studies in vitro have also proved that Wnt10b enhances proliferation and suppresses apoptosis by activation of $\beta$-catenin and c-Myc as well as APC inhibition [102,119]. However, the significance of the WNT10A gene in endometrial cancer, aside from its upregulated expression, remains unknown [120].

Studies by van der Zee et al. demonstrated a synergistic effect of the Wnt/ $\beta$-catenin and PTEN pathways in endometrial cancer [121]. Loss of PTEN function is linked with endometrial cancer onset and PTEN is frequently mutated in endometrioid endometrial tumors [9]. PTEN function loss stimulates defects in the function of the APC that normally regulate the formation of the $\beta$-catenin "destruction complex" that in turn causes constitutive activation of the Wnt $/ \beta$-catenin pathway and promotes the development of cancer. The result of the constitutively activated Wnt/ $\beta$-catenin pathway is squamous cell metaplasia (SCM) with no malignant transformation. Consequently, it appears that activation of the Wnt $\beta$-catenin pathway accelerates rather than initiates the cancer while the simultaneous loss of PTEN activity and activation of the Wnt/ $\beta$-catenin pathway is associated with the development of an aggressive form of endometrial cancer [121].

The other major alteration reported in endometrial cancers is nuclear accumulation of $\beta$-catenin (CTNNB1). Between $10 \%$ and $45 \%$ of endometrial cancers have missense mutations of CTNNB1 [70,73,122]. CTNNB1 mutations are apparently found in the early stages of endometrial carcinogenesis [70]. Many studies show that CTNNB1 mutation is primarily detected in endometrioid endometrial cancer rather than nonendometrioid endometrial carcinoma cases (NEEC) [26,69,122,123]. 
$\beta$-catenin mutations in exon 3 , on the serine/threonine residue that is the site of regulatory phosphorylation by GSK3 $\beta$, have been identified $[24,124]$. Mutations within this domain prevent $\beta$-catenin degradation and result in $\beta$-catenin nuclear accumulation in endometrial tumors. Of 76 uterine endometrial carcinoma cases examined, 10 cases (approximately 13\%) had mutations within this domain; 20 cases (approximately 26\%) without $\beta$-catenin mutations showed similar accumulation of the protein [24]. In total, $38 \%$ of endometrial carcinoma cases showed nuclear accumulation. Those cases that showed $\beta$-catenin accumulation but not the exon $3 \beta$-catenin mutation may have carried alterations in $\beta$-catenin outside of exon 3 , alterations to APC, or had the involvement of members of the Wnt family proteins that elevate $\beta$-catenin expression [125-127]. This study showed that nuclear accumulation of beta-catenin, due to $\beta$-catenin mutations in exon 3 or alternative mechanisms, may play a significant role in development of endometrial carcinomas. Travaglino et al. and Nei et al. observed a $10 \%$ mutation frequency for $\beta$-catenin in endometrial cancer ( $2 / 20$ tumors) while showing that $30 \%$ of endometrial cancer specimens exhibited nuclear $\beta$-catenin accumulation. They found very intense nuclear staining of $\beta$-catenin more often in endometrial hyperplasia than in endometrial carcinoma samples $[28,29]$. Ikeda et al. and others reported an $11 \%$ somatic mutation frequency (5/44 tumors) and that the tumors with mutations exhibited accumulation of the $\beta$-catenin in the cytoplasm and nucleus $[24,28,122]$. Mirabelli-Primdahl et al. identified a $45 \%$ CTNNB1 mutation frequency in 29 endometrial cancer tumors with or without microsatellite instability (33\% MSI-H and 50\% MSS/MSI-L), suggesting that there is no correlation with the presence or absence of underlying microsatellite instability [128]. Schlosshauer et al. and Saegusa have reported slightly higher $\beta$-catenin mutation frequencies (18\% and $23 \%$, respectively) in endometrioid endometrial cancers [27,91], while Moreno-Bueno observed 11\% CTNNB1 mutation frequency in endometrioid endometrial cancer [129]. Recently, Antonio et al. showed that exon 3 CTNNB1 mutations and concomitant nuclear expression of $\beta$-catenin were found in $16.8 \%$ of the 125 endometrial carcinomas studied. Nuclear localization of $\beta$-catenin in neoplastic cells varies between $5 \%$ and $60 \%$ in CTNNB1 mutant endometrial carcinomas (mean 19.8\%) [130]. Another study explored the impact of ARID1A and CTNNB1/-catenin alterations in a group of molecularly classified endometrium cancers using targeted next-generation sequencing (NGS) [131]. Kim et al. showed that exon 3 CTNNB1 mutations were found in 63 (18\%) of 345 endometrial cancer patients; 53 of these patients had tissue available for immunohistochemistry. Among these 53 samples, 46 were of pure endometrioid histology and seven were mixed endometrioid and nonendometrioid carcinomas. This study found that $45 / 53$ (85\%) of CTNNB1 mutant endometrial cancers had nuclear $\beta$-catenin localization [132]. Taken together, these findings suggest that total nuclear $\beta$-catenin may not be as important as previously thought in driving the poor prognosis seen in CTNNB1-mutant endometrial cancers as other cellular components may also help activate the Wnt pathway. Detailed CTNNB1 mutational rates are listed in Table 3.

Table 3. $\beta$-Catenin mutations in endometrial cancer.

\begin{tabular}{ccc}
\hline Study & $\begin{array}{c}\text { Mutation Frequency of Beta } \\
\text { Catenin in Endometrial Cancer (\%) }\end{array}$ & Ref. \\
\hline Fukuchi et al. (1998) & 13 & {$[24]$} \\
Nei et al. (1999) & 10 & {$[28]$} \\
Mirabelli-Primdahl et al. (1999) & 45 & {$[128]$} \\
Ikeda et al. (2000) & 11 & {$[122]$} \\
Moreno-Bueno et al. (2002) & 11 & {$[129]$} \\
Machin et al. (2002) & 21 & {$[26]$} \\
Schlosshauer et al. (2000) & 19 & {$[27]$} \\
Saegusa et al. (2001) & 23 & {$[91]$} \\
Antonio et al. (2021) & 16.8 & {$[130]$} \\
Kim et al. (2018) & 18 & {$[132]$} \\
Kurnit et al. (2017) & 18 & {$[70]$} \\
\hline
\end{tabular}


Another study by Shelton and Goodheart et al. examined the role of lymphoid enhancer-binding factor 1 (Lef1) in endometrial cancer [133]. Lef1, a member of the T cell factor (TCF)/Lef1 family of high-mobility group transcription factors, is a downstream mediator of the Wnt/ $\beta$-catenin signaling pathway, although it can also modulate gene transcription independently. Overexpression of Lef1 has been detected in several cancers, principally colon and colorectal cancers, leukemia, melanoma, and pancreatic cancer, making it a valuable biomarker in predicting patient prognosis. Lef1 is overexpressed in endometrioid endometrial carcinomas compared to nonendometrioid endometrial carcinomas, and where the Lef1 downstream targets are activated through cyclin D1 and MMP7 [134]. An ongoing clinical study (NCT03787056, www.clinicaltrials.gov (accessed on 10 May 2021)), published in Dec 2018 and sponsored by Hospices Civils de Lyon [135], is investigating the predictive value of progastrin titer at diagnosis and of progastrin kinetics during treatment in cancer patients (approximately 410 participants). Progastrin is a prohormone that under physiological conditions is transformed into gastrin in the G cells of the stomach. Gastrin is a hormone that excites the production of gastric acids during digestion. It is also vital for the regulation of gastric mucosal cell growth. Progastrin is not present in the peripheral blood of a healthy person. However, patients with endometrial cancer and other cancers (colorectal, gastric, ovarian, breast, cervix uterus, and melanoma among others) have abnormally high progastrin blood levels. The WNT/B-catenin oncogenic pathway has a direct target gene, GAST, which codes for progastrin [135]. Progastrin, as measured in the peripheral blood of cancer patients undergoing treatment, may thus be a new effective marker for cancer diagnosis and prognosis at various stages.

\section{Pharmacological Wnt Inhibitors and Clinical Trials}

Precision medicine is often limited by the identification of biological mediators, the pathology of various conditions, and the development of treatments that efficiently target specific genes; in addition, treatments often have side effects. Recent research has significantly increased our understanding of the function of Wnt secretion in carcinogenesis and revealed novel therapeutic targets. The Wnt cascade constitutes potential targets for pharmacological intervention and use in personalized medicine; however, the role of the individual $\beta$-catenin pathway components must be better elucidated in endometrial cancer. Currently, very few effective treatment strategies exist for advanced endometrial cancer patients who have failed traditional chemotherapy. Novel biologics targeting VEGF and mTOR pathways have shown promising results for endometrial cancer in phase II clinical trials $[136,137]$. CTNNB1 mutations and epigenetic silencing of negative Wnt regulators contributes to the aberrant activation of $\beta$-catenin and this process can be attenuated at different cellular levels, hence there is a clear need for drugs that interfere with the transcriptional functions of $\beta$-catenin $[138,139]$. Emerging evidence indicates that $\beta$-catenin-dependent signaling plays a crucial role in endometrioid endometrial cancer progression and nuclear $\beta$-catenin could be a novel therapeutic target of endometrial cancer treatment.

Currently, numerous $\beta$-catenin-dependent signaling inhibitors are available as preclinical, trial, or FDA-approved therapies, including MPA, DKN-1, OMP-54F28, Niclosamide, and PRI-724 among others.

\subsection{Medroxyprogesterone Acetate (MPA)}

Wang et al., in a study of 21 patients, showed that a synthetic form of progesterone (medroxyprogesterone acetate, MPA) counteracts the proliferative effects of E2 (estradiol) during the normal menstrual cycle, hyperplasia, and early endometrial carcinogenesis by inhibiting $W n t / \beta$-catenin signaling gene expression [19]. While lesions are expected to disappear with extended use of MPA treatment, when therapy is stopped there is marked recurrence as documented by the Yahata research group in a limited study of six young patients [140]. 


\subsection{Levonorgestrel Intrauterine Device}

In a clinical study, Westin and his research team (clinicaltrials.gov, NCT00788671) documented the effectiveness of a levonorgestrel-releasing intrauterine system in treating patients with complex atypical hyperplasia or grade I endometrial cancer [141]. The aim was to explore hormone replacement therapy using levonorgestrel, a type of progesterone, to combat endometrial cancer. A total of 57 patients were treated ( 21 endometrial cancer, 36 complex atypical hyperplasia); median age was 48 years and the median BMI was $45.5 \mathrm{~kg} / \mathrm{m}^{2}$. Of 47 evaluable patients, the 12 -month response rate was $83 \%$, 37 were complete responders ( 8 endometrial cancer, 29 complex atypical hyperplasia), 2 were partial responders ( 2 endometrial cancer), 3 had stable diseases ( 2 endometrial cancer, 1 complex atypical hyperplasia), and 5 had progressive diseases ( 3 endometrial cancer, 2 complex atypical hyperplasia). Westin has also reported on genes that are important in cell proliferation, estrogen signaling, and Wnt signaling [142].

\section{3. $D K N-01$}

DKN-01 is a humanized monoclonal antibody (Mab) targeting Dickkopf-1 (DKK1) and is being developed as an antineoplastic agent. One study (NCT03395080), started in Feb 2018 and funded by Leap Therapeutics, Inc., uses DKN-01 as a monotherapy or in combination with paclitaxel in patients with recurrent epithelial endometrial or epithelial ovarian cancer or carcinosarcoma [143]. Doses of 300mg DKN-01 will be infused in a total of 124 patients in combination with paclitaxel (18 years and older). In this study, they will also observe response to therapy in patients with and without activating $\beta$-catenin mutations and/or Wnt signaling genetic alterations and with recurrent EEC (epithelial endometrial cancer) or EOC (epithelial ovarian cancer) or carcinosarcoma.

\subsection{Porcupine Inhibitor}

Wnt-driven cancers can be targeted at many points in the pathway $[23,57,138]$. One strategy is to prevent the secretion of all Wnts by inhibiting the activity of Porcupine (PORCN), an endoplasmic reticulum-resident enzyme that palmitoleates Wnts at a highly conserved serine residue post-translationally [144]. Both Wnt secretion and binding to Frizzled receptors are dependent on palmitoleation [145]. Inhibition of PORCN enzymatic activity provides a way to overcome the limitations of $\beta$-catenin inhibitors that can only hinder the canonical Wnt signaling cascade or anti-Frizzled antibodies, which cannot attack all Frizzled receptors [144,146]. Blocking a significant post-translational modification, palmitoleation, provides a useful therapeutic intervention [144]. The Madan research group developed a novel, potent, orally available PORCN inhibitor, ETC-1922159 (henceforth called ETC-159) that blocks the secretion and function of all Wnts. RSPO translocations are seen in $\sim 4-18 \%$ of patients with ovarian, endometrial, and gastric cancer, suggesting that ETC-159 may be a beneficial therapeutic strategy for EC treatment [144]. A clinical trial (Phase 1A/B) is ongoing, employing 83 participants (NCT02521844) and sponsored by the EDDC (Experimental Drug Development Centre), to evaluate the safety and tolerability of ETC-159 in different advanced solid tumors [147]. LGK974, another PORCN inhibitor that has been shown to suppress tumor progression, is currently being evaluated in clinical trials for solid malignancies, including esophageal squamous-cell carcinoma, pancreatic adenocarcinoma, and BRAF-mutated colorectal cancer [148].

\subsection{OMP-54F28}

OMP-54F28 is a fusion protein consisting of the extracellular ligand-binding domain of Fzd8 and a human immunoglobulin G1 (IgG1) Fc domain. This decoy receptor interferes with Wnt signaling by sequestering secreted Wnts and shows antitumor activity in several patient-derived xenograft (PDX) models $[149,150]$. Currently, three phase $1 \mathrm{~b}$ trials of OMP54F28 in combination with chemotherapeutics in liver, ovarian, and pancreatic cancer are ongoing. Furthermore, a phase I clinical trial testing the safety of OMP131R10, a RSPO3binding antibody, in advanced solid tumors and metastasized colorectal cancer has recently 
been completed, although results are as yet unpublished [151]. Several clinical phase I studies have documented Ipafricept (OMP-54F28) as a potent agent to target Wnt ligands in patients with advanced solid tumors [152,153].

\subsection{Niclosamide}

Niclosamide (trade name Niclocide), an FDA-approved salicylamide derivative used for the treatment of tapeworm infections, targets the Wnt/ $\beta$-catenin pathway. Recently, it was observed that niclosamide inhibits the $\beta$-catenin-dependent pathway in ovarian tumor cells isolated from 34 patient ascites [154]. Moreover, the inhibitory effects of niclosamide on Wnt/ $\beta$-catenin signaling were also found in primary human glioblastoma cells [155]. Niclosamide promoted LRP5/ 6 degradation [156], Wnt receptor Fzd1 endocytosis [157], downregulation of Dvl2 proteins, and inhibition of Wnt3A-stimulated $\beta$-catenin stabilization and TCF/LEF reporter activity $[157,158]$ as well as enhanced cytotoxicity in all the patient derived tumor spheres. Niclosamide has also been shown to interfere with $W n t 7 / \beta$-catenin signaling and can reduce tumor growth in a xenograft mouse model [159]. It may be worthwhile to start an in vitro study or a clinical trial in endometrial cancer patients with niclosamide therapy.

\subsection{PRI-724 and ICG-001}

Besides the intracellular perturbation of Wnt secretion and ligands, an inhibitor of the downstream Wnt pathway is currently undergoing clinical trials. Emami et al. developed a small molecule inhibitor (PRI-724) closely related compound ICG-001 that targets the complex formation of $\beta$-catenin and CBP that specifically downregulates the expression of $\beta$-catenin-TCF-responsive genes [160]. Treatment with PRI-724 therefore interferes with Wnt/ $\beta$-catenin signaling and inhibits tumor growth [161]. PRI-724 has been shown to have an acceptable safety profile in a phase 1 clinical trial and is now under further clinical investigation [162]. A phase 2 trial of PRI-724 in combination with bevacizumab is now being planned for metastatic colorectal carcinoma patients (clinicaltrials.gov, 2015, NCT02413853). It may be worthwhile to conduct an in vitro study or a clinical trial in endometrial cancer patients with this PRI-724 and ICG-001 treatment therapy [163].

\subsection{Salinomycin}

Salinomycin, an antibiotic potassium ionophore, is a selective inhibitor of breast cancer stem cells [164]. Salinomycin induces apoptosis, interferes with Wnt/ $\beta$-catenin signaling, and consequently inhibits proliferation, migration, and invasion as well as shows antitumor effects on side population (SP) cells obtained from invasive endometrial cancer cells [165]. Therefore, it is important to examine either salinomycin alone or in combination with other drugs as it could significantly interfere with proliferation, apoptosis, migration, and invasion in human endometrial cancer cells as well as in endometrial cancer stem cells.

\subsection{Curcumin}

Curcumin inhibits the initiation, promotion, and progression of carcinogenesis. Curcumin may exert anticancer effects through a variety of pathways that are involved in mutagenesis, apoptosis, tumorigenesis, cell cycle regulation, and metastasis. The anticancer effects of curcumin involve in the activation of apoptotic pathways as well as in inhibition of tumor microenvironments (inflammation, angiogenesis, and tumor metastasis). Extensive studies have demonstrated that curcumin targets several therapeutically relevant cancer signaling pathways, such as p53, Ras, PI3K, AKT, Wnt/ $\beta$-catenin, and mTOR [166]. Clinical trials also suggest that curcumin either alone or as part of a combination with other drugs possesses promising anticancer effects in cancer patients without toxic side effects $[167,168]$. Feng et al. documented that Curcumin promotes apoptosis in human endometrial carcinoma cells (RL-952) by downregulating the expression of androgen receptors (ER) through inhibition of Wnt signaling [169]. 


\subsection{0. miRNA Treatment}

MicroRNAs (miRNAs) are small noncoding RNAs comprised of about 22 nucleotides that are a class of naturally occurring small noncoding RNA molecules that regulate cellular function by controlling multiple target messenger RNAs. A single miRNA may target at least 200 genes and a single gene can be regulated by many RNAs. Since individual miRNAs have potentially numerous target genes, miRNA dysregulation can profoundly regulate the cellular machinery and facilitate cancer hallmarks [170]. Numerous pieces of research have proved that dysregulation of microRNAs enhance tumorigenesis and metastasis. Furthermore, recent studies have shown that miRNAs can act as either potent oncogenes or tumor-suppressor genes. To understand the role of miRNAs in endometrial cancer, all miRNAs where regulation has been shown are extensively reviewed in this section.

Wang et al. documented that miR-15a-5p levels are significantly decreased in endometrial cancer compared with healthy controls both in in vitro and in vivo [171]. In this study, endometrial cancer tissues were obtained from patients who underwent a hysterectomy. The tissue samples included eight endometrial cancer tissues and three normal control tissues. They confirmed that miR-15a-5p suppresses endometrial cancer cell growth via Wnt/ $\beta$-catenin signaling by inhibiting WNT3A [171]. Overexpression of miR-21 has also been reported in endometrioid endometrial cancer. Xiaoyan et al. demonstrated that miR-21 expression was inversely correlated with PTEN protein expression in the KLE cell line. The overexpression of miR-21 results in downregulation of PTEN, leading to the modulation of endometrioid endometrial cancer cell proliferation [172]. Over the last decade, several researchers have documented that miR-21 promotes progression of numerous cancers via the Wnt/ $\beta$-catenin pathway [173-175]. Additionally, miR-146b-5p is dramatically decreased in the endometrial carcinoma cell line Ishikawa compared with normal endometrial cells. Progesterone has been shown to regulate the NEAT1/miR-146b-5p axis via the $\mathrm{Wnt} / \beta$-catenin signaling pathway. In this study, progesterone exerted suppressive influence on endometrial cancer progression via regulation of the lncRNA NEAT1/miR$146 \mathrm{~b}-5 \mathrm{p}$-mediated $\mathrm{Wnt} / \beta$-catenin signaling pathway, potentially revealing new strategies for developing more effective therapeutics [176]. Although, the miR-200 family (a/b/c) has been shown to be downregulated in most type of cancers, the upregulation seen in endometrial carcinoma is also seen in ovarian carcinoma, melanoma, and colorectal carcinoma $[177,178]$. In addition, miR-200a has been shown to directly interact with the $3^{\prime}$ UTR of CTNNB1 to suppress Wnt / $\beta$-catenin signaling in SGC790 and U251 cells [179]. Moreover, downregulation of miR-200a promotes epithelial-mesenchymal transition in gastric adenocarcinoma and brain meningiomas and arachnoidal cells [180,181]. Thus, the function of upregulated microRNA-200a and its relationship to Wnt signaling in endometrial cancer is still unknown.

To date, the use of various inhibitors of Wnt / $\beta$-catenin targeting cancer as prognostic markers and tumor suppressors has been reported and novel agents targeting the Wnt $/ \beta$ catenin signaling pathway have shown encouraging results. Endometrial cancer should be the focus of these initiatives with the goal of establishing Wnt pathway components as prognostic and predictive biomarkers as well as demonstrating preclinical evidence and assessing the efficacy of established inhibitors for this pathway.

\section{Wnt Signaling Crosstalk: An emerging Area for Drug Development}

The Wnt signaling pathway has been shown to be involved in crosstalk with several other signaling pathways, such as the Notch, mTOR, Hedgehog, and estrogen signaling pathways, and with the tissue microenvironment. Since endometrial cancer pathogenesis involves various genomic changes and aberrant signaling pathways; investigating the association between the incidence of these molecular disorders and their plausible crosstalk will potentially reveal important targets for synergistic drug combinations in endometrial cancer and advance the development of targeted and more successful therapies [182,183]. 
Cancer stem cell (CSC) activation of the Wnt pathway has been shown to initiate a complex transcriptional program resulting in the expression of genes involved in drug resistance (such as ABCB1 and CD44) and immune function (such as PD-L1 and CD47) [184]. A recent study identified SPARC-related modular calcium-binding 2 (SMOC-2) as a novel endometrial cancer stem cell signature gene and demonstrated that SMOC-2 is involved in activation of the Wnt/ $\beta$-catenin pathway [185]. Furthermore, salinomycin, an antibacterial and coccidiostatic therapeutic drug that is a selective inhibitor of CSCs, has been shown to downregulate the expression of Wnt target genes such as LEF1, cyclin D1, and fibronectin [165]. Given the prominent role of the Wnt signaling cascade in stem cell biology, the study of endometrial cancer stem cells seems to be a promising area of central focus in the near future and has prospects for safely and effectively targeting this signaling to abolish the cancer stem cell population in endometrial cancer.

Wnt signaling acts as a bridge between tumor cells and the tumor microenvironment contributing to cancer progression, drug resistance, and immunity escape [186]. While Wnt signaling plays a major role in cellular homeostasis, regulating immune cell development and function, Wnt ligands secreted by stromal cells and inflammatory cells present in the tumor microenvironment promote tumor invasion, metastasis, and tolerance [186]. Therefore, the role of Wnt signaling in immune cells is becoming an area of active research. With the recent progress in immunotherapy, the combination therapy with modulation of $W n t / \beta$-catenin signaling is expected to overcome primary, adaptive, and acquired resistance to cancer immunotherapy and to add therapeutic benefit in personalized molecular therapy for women with advanced and recurrent endometrial cancer $[187,188]$. A recent study demonstrated tumor necrosis factor receptor-associated factor 6 (TRAF6) as a key regulatory factor for Wnt3a-induced regulation of $\beta$-catenin and subsequent activation of Wnt3a target genes implicated in prostate cancer progression, suggesting TRAF6 as an important novel target for inhibiting cancer [189].

Increasing evidence for the crosstalk between $\mathrm{Wnt} / \beta$-catenin and autophagy suggests the interplay between both pathways as an attractive therapeutic target [190]. Hydroxychloroquine, chloroquine, bafilomycin, and concanamycin, which are well known autophagy inhibitors, have been shown to inhibit Wnt/ $\beta$-catenin signaling via inhibiting v-ATPase in CRC, suggesting their use as cancer-specific Wnt/ $\beta$-catenin inhibitors $[148,191,192]$. However, further research is warranted regarding the safety and efficacy in endometrial cancer.

Unopposed estrogen and Wnt signaling aberrations are major pathways accounting for the endometrial cancers. A study using a uterine epithelial cell specific inducible Cre mouse model and 3D in vitro culture of human endometrial cancer cell lines demonstrated interplay between hormone and Wnt signaling pathways in endometrial cancer. This study showed that activating mutations in the Wnt signaling pathway for a prolonged period is insufficient to cause endometrial cancer but leads to development of endometrial hyperplasia. However, together with unopposed estrogen, activating mutations in Wnt signaling drive the progression of endometrial hyperplasia to endometrial cancer. Overall, this study indicated use of progesterone as a targeted therapy for endometrial cancer patients with an activated Wnt signaling pathway [193]. Another study demonstrated progesterone-mediated regulation of the Wnt/ $\beta$-catenin signaling pathway via regulation of $\operatorname{lncRNA}$ NEAT1/miR-146b-5p contributing to endometrial cancer growth inhibition [176]. Feng et al. also showed that progesterone treatment suppressed the Wnt signaling as well as $\beta$-catenin via suppressing the level of $\mathrm{H} 19$, which directly targets miR152 [194]. Altogether, these studies unravel new strategies for developing more effective therapeutics. However, there is still a lack of studies evaluating the combined effect of progesterone and Wnt signaling inhibitors.

\section{Conclusions and Future Perspective}

Abnormal activation of WNT signaling has been reported in the majority of type1 endometrial cancer cases with $\beta$-catenin mutations in $20-25 \%$ of cases. Given the current lack of treatment options for advanced and recurrent endometrial cancer patients and 
the growing body of evidence supporting the role of Wnt signaling at early stages of endometrial carcinogenesis, Wnt signaling represents a promising intervention for targeted therapies in endometrial cancer patients. Various inhibitors targeting different molecules of this pathway have been developed, though only a few studies have addressed the effects of Wnt inhibitors in endometrial cancer and they are still at an early phase and far away from clinical trials. Future studies evaluating the efficacy and safety of Wnt/ $\beta$-catenin signaling inhibitors in endometrial cancer are needed to aid in the development of targeted novel therapies that can reverse the increasing trend of mortality in endometrial cancer patients. With the recent advances in genome editing, further research utilizing humanderived organoid models and tissue-specific inhibition of Wnt signaling will enhance our understanding and identify novel targets of the $\mathrm{Wnt} / \beta$-catenin signaling pathway in endometrial cancer. Since combination therapy with other cancer drugs has been shown to limit off-target toxicities and considering the contribution of the crosstalk between Wnt signaling and the host immune response to therapeutic resistance and immune escape, Wnt inhibitors in combination with immunotherapies must be evaluated in endometrial cancer to improve both overall treatment efficacy and patient outcomes.

Author Contributions: Conceptualization, I.F., S.B. and V.C.; resources, V.C.; writing-original draft preparation, I.F. and S.B.; writing-review and editing, K.W.T., R.R. and V.C.; visualization, I.F., S.B., R.R. and V.C.; supervision, R.R. and V.C.; project administration, V.C.; funding acquisition, V.C. All authors have read and agreed to the published version of the manuscript.

Funding: This research received no external funding.

Institutional Review Board Statement: Not applicable.

Informed Consent Statement: Not applicable.

Data Availability Statement: Not Applicable.

Conflicts of Interest: The authors declare no conflict of interest.

\section{References}

1. Jabbour, H.N.; Kelly, R.W.; Fraser, H.M.; Critchley, H.O.D. Endocrine Regulation of Menstruation. Endocr. Rev. 2006, 27, 17-46. [CrossRef] [PubMed]

2. Gargett, B.E.; Chan, R.W.S. Endometrial Stem/Progenitor Cells and Proliferative Disorders of the Endometrium. Minerva Ginecol. 2006, 58, 511-526. [PubMed]

3. Tetikkurt, S.; Çelik, E.; Taş, H.; Cay, T.; Işik, S.; Usta, A.T. Coexistence of Adenomyosis, Adenocarcinoma, Endometrial and Myometrial Lesions in Resected Uterine Specimens. Mol. Clin. Oncol. 2018, 9, 231-237. [CrossRef] [PubMed]

4. Soslow, R.A. High-Grade Endometrial Carcinomas-Strategies for Typing. Histopathology 2013, 62, 89-110. [CrossRef] [PubMed]

5. Cancer of the Endometrium-Cancer Stat Facts. Available online: https://seer.cancer.gov/statfacts/html/corp.html (accessed on 28 March 2021).

6. Street, W. Cancer Facts \& Figures. 2020. Available online: https://www.cancer.org/research/cancer-facts-statistics/all-cancerfacts-figures / cancer-facts-figures-2020.html (accessed on 10 May 2021).

7. Sheikh, M.A.; Althouse, A.D.; Freese, K.E.; Soisson, S.; Edwards, R.P.; Welburn, S.; Sukumvanich, P.; Comerci, J.; Kelley, J.; LaPorte, R.E.; et al. USA Endometrial Cancer Projections to 2030: Should We Be Concerned? Future Oncol. 2014, 10, 2561-2568. [CrossRef]

8. Cote, M.L.; Ruterbusch, J.J.; Olson, S.H.; Lu, K.; Ali-Fehmi, R. The Growing Burden of Endometrial Cancer: A Major Racial Disparity Affecting Black Women. Cancer Epidemiol. Biomark. Prev. 2015, 24, 1407-1415. [CrossRef] [PubMed]

9. Cancer Genome Atlas Research Network; Kandoth, C.; Schultz, N.; Cherniack, A.D.; Akbani, R.; Liu, Y.; Shen, H.; Robertson, A.G.; Pashtan, I.; Shen, R.; et al. Integrated Genomic Characterization of Endometrial Carcinoma. Nature 2013, 497, 67-73. [CrossRef]

10. Ma, X.; Ma, C.X.; Wang, J. Endometrial Carcinogenesis and Molecular Signaling Pathways. Am. J. Mol. Biol. 2014, 2014. [CrossRef]

11. Bilyk, O.; Coatham, M.; Jewer, M.; Postovit, L.-M. Epithelial-to-Mesenchymal Transition in the Female Reproductive Tract: From Normal Functioning to Disease Pathology. Front. Oncol. 2017, 7. [CrossRef]

12. Polakis, P. Wnt Signaling and Cancer. Genes Dev. 2000, 14, 1837-1851. [CrossRef]

13. Inestrosa, N.C.; Montecinos-Oliva, C.; Fuenzalida, M. Wnt Signaling: Role in Alzheimer Disease and Schizophrenia. J. Neuroimmune Pharmacol. 2012, 7, 788-807. [CrossRef] [PubMed]

14. Luo, J.; Chen, J.; Deng, Z.-L.; Luo, X.; Song, W.-X.; Sharff, K.A.; Tang, N.; Haydon, R.C.; Luu, H.H.; He, T.-C. Wnt Signaling and Human Diseases: What Are the Therapeutic Implications? Lab. Investig. 2007, 87, 97-103. [CrossRef] [PubMed]

15. Ring, A.; Kim, Y.-M.; Kahn, M. Wnt/Catenin Signaling in Adult Stem Cell Physiology and Disease. Stem Cell Rev. Rep. 2014, 10, 512-525. [CrossRef] [PubMed] 
16. Novellasdemunt, L.; Antas, P.; Li, V.S.W. Targeting Wnt Signaling in Colorectal Cancer. A Review in the Theme: Cell Signaling: Proteins, Pathways and Mechanisms. Am. J. Physiol. Cell Physiol. 2015, 309, C511-C521. [CrossRef]

17. Prestwich, T.C.; MacDougald, O.A. Wnt/ $\beta$-Catenin Signaling in Adipogenesis and Metabolism. Curr. Opin. Cell Biol. 2007, 19, 612-617. [CrossRef] [PubMed]

18. Van der Horst, P.H.; Wang, Y.; van der Zee, M.; Burger, C.W.; Blok, L.J. Interaction between Sex Hormones and WNT/ $\beta$-Catenin Signal Transduction in Endometrial Physiology and Disease. Mol. Cell. Endocrinol. 2012, 358, 176-184. [CrossRef] [PubMed]

19. Wang, Y.; Hanifi-Moghaddam, P.; Hanekamp, E.E.; Kloosterboer, H.J.; Franken, P.; Veldscholte, J.; van Doorn, H.C.; Ewing, P.C.; Kim, J.J.; Grootegoed, J.A.; et al. Progesterone Inhibition of Wnt/ $\beta$-Catenin Signaling in Normal Endometrium and Endometrial Cancer. Clin. Cancer Res. 2009, 15, 5784-5793. [CrossRef]

20. Chandra, V.; Fatima, I.; Manohar, M.; Popli, P.; Sirohi, V.K.; Hussain, M.K.; Hajela, K.; Sankhwar, P.; Dwivedi, A. Inhibitory Effect of 2-(Piperidinoethoxyphenyl)-3-(4-Hydroxyphenyl)-2H-Benzo(b)Pyran (K-1) on Human Primary Endometrial Hyperplasial Cells Mediated via Combined Suppression of Wnt/ $\beta$-Catenin Signaling and PI3K/Akt Survival Pathway. Cell Death Dis. 2014, 5, e1380. [CrossRef]

21. Ilyas, M. Wnt Signalling and the Mechanistic Basis of Tumour Development. J. Pathol. 2005, 205, 130-144. [CrossRef] [PubMed]

22. Dellinger, T.H.; Planutis, K.; Tewari, K.S.; Holcombe, R.F. Role of Canonical Wnt Signaling in Endometrial Carcinogenesis. Expert Rev. Anticancer Ther. 2012, 12, 51-62. [CrossRef] [PubMed]

23. Arend, R.C.; Londoño-Joshi, A.I.; Straughn, J.M.; Buchsbaum, D.J. The Wnt/ $\beta$-Catenin Pathway in Ovarian Cancer: A Review. Gynecol. Oncol. 2013, 131, 772-779. [CrossRef]

24. Fukuchi, T.; Sakamoto, M.; Tsuda, H.; Maruyama, K.; Nozawa, S.; Hirohashi, S. $\beta$-Catenin Mutation in Carcinoma of the Uterine Endometrium. Cancer Res. 1998, 58, 3526-3528.

25. Sparks, A.B.; Morin, P.J.; Vogelstein, B.; Kinzler, K.W. Mutational Analysis of the APC/ $\beta$-Catenin/Tcf Pathway in Colorectal Cancer. Cancer Res. 1998, 58, 1130-1134.

26. Machin, P.; Catasus, L.; Pons, C.; Muñoz, J.; Matias-Guiu, X.; Prat, J. CTNNB1 Mutations and $\beta$-Catenin Expression in Endometrial Carcinomas. Hum. Pathol. 2002, 33, 206-212. [CrossRef]

27. Schlosshauer, P.W.; Pirog, E.C.; Levine, R.L.; Ellenson, L.H. Mutational Analysis of the CTNNB1 and APC Genes in Uterine Endometrioid Carcinoma. Mod. Pathol. 2000, 13, 1066-1071. [CrossRef]

28. Nei, H.; Saito, T.; Yamasaki, H.; Mizumoto, H.; Ito, E.; Kudo, R. Nuclear Localization of $\beta$-Catenin in Normal and Carcinogenic Endometrium. Mol. Carcinog. 1999, 25, 207-218. [CrossRef]

29. Travaglino, A.; Raffone, A.; Saccone, G.; Mascolo, M.; D’Alessandro, P.; Arduino, B.; Mollo, A.; Insabato, L.; Zullo, F. Nuclear Expression of $\beta$-Catenin in Endometrial Hyperplasia as Marker of Premalignancy. APMIS 2019, 127, 699-709. [CrossRef] [PubMed]

30. Su, H.-Y.; Lai, H.-C.; Lin, Y.-W.; Chou, Y.-C.; Liu, C.-Y.; Yu, M.-H. An Epigenetic Marker Panel for Screening and Prognostic Prediction of Ovarian Cancer. Int. J. Cancer 2009, 124, 387-393. [CrossRef]

31. Su, H.-Y.; Lai, H.-C.; Lin, Y.-W.; Liu, C.-Y.; Chen, C.-K.; Chou, Y.-C.; Lin, S.-P.; Lin, W.-C.; Lee, H.-Y.; Yu, M.-H. Epigenetic Silencing of SFRP5 Is Related to Malignant Phenotype and Chemoresistance of Ovarian Cancer through Wnt Signaling Pathway. Int. J. Cancer 2010, 127, 555-567. [CrossRef]

32. Carmon, K.S.; Loose, D.S. Secreted Frizzled-Related Protein 4 Regulates Two Wnt7a Signaling Pathways and Inhibits Proliferation in Endometrial Cancer Cells. Mol. Cancer Res. 2008, 6, 1017-1028. [CrossRef]

33. Saran, U.; Arfuso, F.; Zeps, N.; Dharmarajan, A. Secreted Frizzled-Related Protein 4 Expression Is Positively Associated with Responsiveness to Cisplatin of Ovarian Cancer Cell Lines In Vitro and with Lower Tumour Grade in Mucinous Ovarian Cancers. BMC Cell Biol. 2012, 13, 25. [CrossRef]

34. Horvath, L.G.; Lelliott, J.E.; Kench, J.G.; Lee, C.-S.; Williams, E.D.; Saunders, D.N.; Grygiel, J.J.; Sutherland, R.L.; Henshall, S.M. Secreted Frizzled-Related Protein 4 Inhibits Proliferation and Metastatic Potential in Prostate Cancer. Prostate 2007, 67, 1081-1090. [CrossRef]

35. Hoang, B.H.; Kubo, T.; Healey, J.H.; Yang, R.; Nathan, S.S.; Kolb, E.A.; Mazza, B.; Meyers, P.A.; Gorlick, R. Dickkopf 3 Inhibits Invasion and Motility of Saos-2 Osteosarcoma Cells by Modulating the Wnt- $\beta$-Catenin Pathway. Cancer Res. 2004, 64, $2734-2739$. [CrossRef]

36. Veeck, J.; Dahl, E. Targeting the Wnt Pathway in Cancer: The Emerging Role of Dickkopf-3. Biochim. Biophys. Acta BBA Rev. Cancer 2012, 1825, 18-28. [CrossRef]

37. Valencia, A.; Román-Gómez, J.; Cervera, J.; Such, E.; Barragán, E.; Bolufer, P.; Moscardó, F.; Sanz, G.F.; Sanz, M.A. Wnt Signaling Pathway Is Epigenetically Regulated by Methylation of Wnt Antagonists in Acute Myeloid Leukemia. Leukemia 2009, 23, 1658-1666. [CrossRef]

38. Aguilera, O.; Fraga, M.F.; Ballestar, E.; Paz, M.F.; Herranz, M.; Espada, J.; García, J.M.; Muñoz, A.; Esteller, M.; González-Sancho, J.M. Epigenetic Inactivation of the Wnt Antagonist DICKKOPF-1 (DKK-1) Gene in Human Colorectal Cancer. Oncogene 2006, 25, 4116-4121. [CrossRef]

39. Fong, D.; Hermann, M.; Untergasser, G.; Pirkebner, D.; Draxl, A.; Heitz, M.; Moser, P.; Margreiter, R.; Hengster, P.; Amberger, A. Dkk-3 Expression in the Tumor Endothelium: A Novel Prognostic Marker of Pancreatic Adenocarcinomas. Cancer Sci. 2009, 100, 1414-1420. [CrossRef] 
40. Yi, N.; Liao, Q.-P.; Li, T.; Xiong, Y. Novel Expression Profiles and Invasiveness-Related Biology Function of DKK1 in Endometrial Carcinoma. Oncol. Rep. 2009, 21, 1421-1427. [CrossRef]

41. Madan, B.; Virshup, D.M. Targeting Wnts at the Source-New Mechanisms, New Biomarkers, New Drugs. Mol. Cancer 2015, 14, 1087-1094. [CrossRef]

42. Kohn, A.D.; Moon, R.T. Wnt and Calcium Signaling: $\beta$-Catenin-Independent Pathways. Cell Calcium 2005, 38, 439-446. [CrossRef]

43. Wang, Y. Wnt/Planar Cell Polarity Signaling: A New Paradigm for Cancer Therapy. Mol. Cancer 2009, 8, 2103-2109. [CrossRef]

44. Dijksterhuis, J.P.; Petersen, J.; Schulte, G. WNT/Frizzled Signalling: Receptor-Ligand Selectivity with Focus on FZD-G Protein Signalling and Its Physiological Relevance: IUPHAR Review 3. Br. J. Pharmacol. 2014, 171, 1195-1209. [CrossRef]

45. Olsen, J.J.; Pohl, S.Ö.-G.; Deshmukh, A.; Visweswaran, M.; Ward, N.C.; Arfuso, F.; Agostino, M.; Dharmarajan, A. The Role of Wnt Signalling in Angiogenesis. Clin. Biochem. Rev. 2017, 38, 131-142.

46. Seidensticker, M.J.; Behrens, J. Biochemical Interactions in the Wnt Pathway. Biochim. Biophys. Acta BBA Mol. Cell Res. 2000, 1495, 168-182. [CrossRef]

47. Nishita, M.; Enomoto, M.; Yamagata, K.; Minami, Y. Cell/Tissue-Tropic Functions of Wnt5a Signaling in Normal and Cancer Cells. Trends Cell Biol. 2010, 20, 346-354. [CrossRef]

48. Habu, M.; Koyama, H.; Kishida, M.; Kamino, M.; Iijima, M.; Fuchigami, T.; Tokimura, H.; Ueda, M.; Tokudome, M.; Koriyama, C.; et al. Ryk Is Essential for Wnt-5a-Dependent Invasiveness in Human Glioma. J. Biochem. 2014, 156, 29-38. [CrossRef]

49. Golubkov, V.S.; Chekanov, A.V.; Cieplak, P.; Aleshin, A.E.; Chernov, A.V.; Zhu, W.; Radichev, I.A.; Zhang, D.; Dong, P.D.; Strongin, A.Y. The Wnt/Planar Cell Polarity Protein-Tyrosine Kinase-7 (PTK7) Is a Highly Efficient Proteolytic Target of Membrane Type-1 Matrix Metalloproteinase: Implications in Cancer and Embryogenesis. J. Biol. Chem. 2010, 285, 35740-35749. [CrossRef]

50. Habas, R.; Kato, Y.; He, X. Wnt/Frizzled Activation of Rho Regulates Vertebrate Gastrulation and Requires a Novel Formin Homology Protein Daam1. Cell 2001, 107, 843-854. [CrossRef]

51. Ford, C.E.; Jary, E.; Ma, S.S.Q.; Nixdorf, S.; Heinzelmann-Schwarz, V.A.; Ward, R.L. The Wnt Gatekeeper SFRP4 Modulates EMT, Cell Migration and Downstream Wnt Signalling in Serous Ovarian Cancer Cells. PLoS ONE 2013, 8, e54362. [CrossRef]

52. Xue, A.G.; Chan, M.; Gujral, T.S. Pan-Cancer Analysis of the Developmental Pathways Reveals Non-Canonical Wnt Signaling as a Driver of Mesenchymal-Type Tumors. Transl. Res. 2020, 224, 1-15. [CrossRef]

53. Zmarzły, N.; Hermyt, E.; Kruszniewska-Rajs, C.; Gola, J.; Witek, A.; Mazurek, U.; Ostenda, A.; Boroń, D. Expression Profile of EMT-Related Genes and MiRNAs Involved in Signal Transduction via the Wnt Pathway and Cadherins in Endometrial Cancer. Available online: https:/ / www.ingentaconnect.com/content/ben/cpb/pre-prints/content-33342410 (accessed on 28 March 2021).

54. Ford, C.E.; Henry, C.; Llamosas, E.; Djordjevic, A.; Hacker, N. Wnt Signalling in Gynaecological Cancers: A Future Target for Personalised Medicine? Gynecol. Oncol. 2016, 140, 345-351. [CrossRef]

55. Nusse, R.; Varmus, H.E. Many Tumors Induced by the Mouse Mammary Tumor Virus Contain a Provirus Integrated in the Same Region of the Host Genome. Cell 1982, 31, 99-109. [CrossRef]

56. Nusse, R.; van Ooyen, A.; Cox, D.; Fung, Y.K.T.; Varmus, H. Mode of Proviral Activation of a Putative Mammary Oncogene (Int -1) on Mouse Chromosome 15. Nature 1984, 307, 131-136. [CrossRef]

57. Anastas, J.N.; Moon, R.T. WNT Signalling Pathways as Therapeutic Targets in Cancer. Nat. Rev. Cancer 2013, 13, 11-26. [CrossRef]

58. Klarmann, G.J.; Decker, A.; Farrar, W.L. Epigenetic Gene Silencing in the Wnt Pathway in Breast Cancer. Epigenetics 2008, 3, 59-63. [CrossRef]

59. Minke, K.S.; Staib, P.; Puetter, A.; Gehrke, I.; Gandhirajan, R.K.; Schlösser, A.; Schmitt, E.K.; Hallek, M.; Kreuzer, K.-A. Small Molecule Inhibitors of WNT Signaling Effectively Induce Apoptosis in Acute Myeloid Leukemia Cells. Eur. J. Haematol. 2009, 82, 165-175. [CrossRef]

60. Matsuda, Y.; Schlange, T.; Oakeley, E.J.; Boulay, A.; Hynes, N.E. WNT Signaling Enhances Breast Cancer Cell Motility and Blockade of the WNT Pathway by SFRP1 Suppresses MDA-MB-231 Xenograft Growth. Breast Cancer Res. 2009, 11, R32. [CrossRef]

61. Ayachi, I.E.; Fatima, I.; Wend, P.; Alva-Ornelas, J.A.; Runke, S.; Kuenzinger, W.L.; Silva, J.; Silva, W.; Gray, J.K.; Lehr, S.; et al. The WNT10B Network Is Associated with Survival and Metastases in Chemoresistant Triple-Negative Breast Cancer. Cancer Res. 2019, 79, 982-993. [CrossRef]

62. Fatima, I.; El-Ayachi, I.; Taotao, L.; Lillo, M.A.; Krutilina, R.; Seagroves, T.N.; Radaszkiewicz, T.W.; Hutnan, M.; Bryja, V.; Krum, S.A.; et al. The Natural Compound Jatrophone Interferes with Wnt/ $\beta$-Catenin Signaling and Inhibits Proliferation and EMT in Human Triple-Negative Breast Cancer. PLoS ONE 2017, 12, e0189864. [CrossRef]

63. Fatima, I.; El-Ayachi, I.; Playa, H.C.; Alva-Ornelas, J.A.; Khalid, A.B.; Kuenzinger, W.L.; Wend, P.; Pence, J.C.; Brakefield, L.; Krutilina, R.I.; et al. Simultaneous Multi-Organ Metastases from Chemo-Resistant Triple-Negative Breast Cancer Are Prevented by Interfering with WNT-Signaling. Cancers 2019, 11, 2039. [CrossRef] [PubMed]

64. Jass, J.R. APC Mutation and Tumour Budding in Colorectal Cancer. J. Clin. Pathol. 2003, 56, 69-73. [CrossRef]

65. Hazra, A.; Fuchs, C.S.; Chan, A.T.; Giovannucci, E.L.; Hunter, D.J. Association of the TCF7L2 Polymorphism with Colorectal Cancer and Adenoma Risk. Cancer Causes Control 2008, 19, 975-980. [CrossRef]

66. Sanz-Pamplona, R.; Lopez-Doriga, A.; Paré-Brunet, L.; Lázaro, K.; Bellido, F.; Alonso, M.H.; Aussó, S.; Guinó, E.; Beltrán, S.; Castro-Giner, F.; et al. Exome Sequencing Reveals AMER1 as a Frequently Mutated Gene in Colorectal Cancer. Clin. Cancer Res. 2015, 21, 4709-4718. [CrossRef]

67. Jin, L.-H.; Shao, Q.-J.; Luo, W.; Ye, Z.-Y.; Li, Q.; Lin, S.-C. Detection of Point Mutations of the Axin1 Gene in Colorectal Cancers. Int. J. Cancer 2003, 107, 696-699. [CrossRef] 
68. Ahadova, A.; von Knebel Doeberitz, M.; Bläker, H.; Kloor, M. CTNNB1-Mutant Colorectal Carcinomas with Immediate Invasive Growth: A Model of Interval Cancers in Lynch Syndrome. Fam. Cancer 2016, 15, 579-586. [CrossRef]

69. McConechy, M.K.; Ding, J.; Senz, J.; Yang, W.; Melnyk, N.; Tone, A.A.; Prentice, L.M.; Wiegand, K.C.; McAlpine, J.N.; Shah, S.P.; et al. Ovarian and Endometrial Endometrioid Carcinomas Have Distinct CTNNB1 and PTEN Mutation Profiles. Mod. Pathol. 2014, 27, 128-134. [CrossRef]

70. Kurnit, K.C.; Kim, G.N.; Fellman, B.M.; Urbauer, D.L.; Mills, G.B.; Zhang, W.; Broaddus, R.R. CTNNB1 (Beta-Catenin) Mutation Identifies Low Grade, Early Stage Endometrial Cancer Patients at Increased Risk of Recurrence. Mod. Pathol. 2017, 30, $1032-1041$. [CrossRef]

71. Delmas, A.L.; Riggs, B.M.; Pardo, C.E.; Dyer, L.M.; Darst, R.P.; Izumchenko, E.G.; Monroe, M.; Hakam, A.; Kladde, M.P.; Siegel, E.M.; et al. WIF1 Is a Frequent Target for Epigenetic Silencing in Squamous Cell Carcinoma of the Cervix. Carcinogenesis 2011, 32, 1625-1633. [CrossRef] [PubMed]

72. Bhagat, R.; Chadaga, S.; Premalata, C.S.; Ramesh, G.; Ramesh, C.; Pallavi, V.R.; Krishnamoorthy, L. Aberrant Promoter Methylation of the RASSF1A and APC Genes in Epithelial Ovarian Carcinoma Development. Cell Oncol. 2012, 35, 473-479. [CrossRef]

73. Palacios, J.; Gamallo, C. Mutations in the $\beta$-Catenin Gene (CTNNB1) in Endometrioid Ovarian Carcinomas. Cancer Res. 1998, 58, 1344-1347. [PubMed]

74. Gerstein, A.V.; Almeida, T.A.; Zhao, G.; Chess, E.; Shih, I.-M.; Buhler, K.; Pienta, K.; Rubin, M.A.; Vessella, R.; Papadopoulos, N. APC/CTNNB1 ( $\beta$-Catenin) Pathway Alterations in Human Prostate Cancers. Genes Chromosomes Cancer 2002, 34, 9-16. [CrossRef] [PubMed]

75. Yardy, G.W.; Brewster, S.F. Wnt Signalling and Prostate Cancer. Prostate Cancer Prostatic Dis. 2005, 8, 119-126. [CrossRef] [PubMed]

76. Wang, Z.; Wang, Y.; Zhang, J.; Hu, Q.; Zhi, F.; Zhang, S.; Mao, D.; Zhang, Y.; Liang, H. Significance of the TMPRSS2:ERG Gene Fusion in Prostate Cancer. Mol. Med. Rep. 2017, 16, 5450-5458. [CrossRef] [PubMed]

77. Scott, R.H.; Murray, A.; Baskcomb, L.; Turnbull, C.; Loveday, C.; Al-Saadi, R.; Williams, R.; Breatnach, F.; Gerrard, M.; Hale, J.; et al. Stratification of Wilms Tumor by Genetic and Epigenetic Analysis. Oncotarget 2012, 3, 327-335. [CrossRef]

78. Wu, Y.; Li, J.; Sun, C.Y.; Zhou, Y.; Zhao, Y.F.; Zhang, S.J. Epigenetic Inactivation of the Canonical Wnt Antagonist Secreted Frizzled-Related Protein 1 in Hepatocellular Carcinoma Cells. Neoplasma 2012, 59, 326-332. [CrossRef]

79. Ding, X.; Yang, Y.; Han, B.; Du, C.; Xu, N.; Huang, H.; Cai, T.; Zhang, A.; Han, Z.-G.; Zhou, W.; et al. Transcriptomic Characterization of Hepatocellular Carcinoma with CTNNB1 Mutation. PLoS ONE 2014, 9, e95307. [CrossRef]

80. Clevers, H. Axin and Hepatocellular Carcinomas. Nat. Genet. 2000, 24, 206-208. [CrossRef]

81. Csepregi, A.; Röcken, C.; Hoffmann, J.; Gu, P.; Saliger, S.; Müller, O.; Schneider-Stock, R.; Kutzner, N.; Roessner, A.; Malfertheiner, P.; et al. APC Promoter Methylation and Protein Expression in Hepatocellular Carcinoma. J. Cancer Res. Clin. Oncol. 2008, 134, 579-589. [CrossRef]

82. Di Magliano, M.P.; Biankin, A.V.; Heiser, P.W.; Cano, D.A.; Gutierrez, P.J.A.; Deramaudt, T.; Segara, D.; Dawson, A.C.; Kench, J.G.; Henshall, S.M.; et al. Common Activation of Canonical Wnt Signaling in Pancreatic Adenocarcinoma. PLoS ONE 2007, 2, e1155. [CrossRef]

83. Horii, A.; Nakatsuru, S.; Miyoshi, Y.; Ichii, S.; Nagase, H.; Ando, H.; Yanagisawa, A.; Tsuchiya, E.; Kato, Y.; Nakamura, Y. Frequent Somatic Mutations of the APC Gene in Human Pancreatic Cancer. Cancer Res. 1992, 52, 6696-6698.

84. Qin, R.-F.; Zhang, J.; Huo, H.-R.; Yuan, Z.-J.; Xue, J.-D. MiR-205 Mediated APC Regulation Contributes to Pancreatic Cancer Cell Proliferation. World J. Gastroenterol. 2019, 25, 3775-3786. [CrossRef]

85. Zhou, C.; Liang, Y.; Zhou, L.; Yan, Y.; Liu, N.; Zhang, R.; Huang, Y.; Wang, M.; Tang, Y.; Ali, D.W.; et al. TSPAN1 Promotes Autophagy Flux and Mediates Cooperation between WNT-CTNNB1 Signaling and Autophagy via the MIR454-FAM83ATSPAN1 Axis in Pancreatic Cancer. Autophagy 2020, 1-21. [CrossRef]

86. Jiang, X.; Hao, H.-X.; Growney, J.D.; Woolfenden, S.; Bottiglio, C.; Ng, N.; Lu, B.; Hsieh, M.H.; Bagdasarian, L.; Meyer, R.; et al. Inactivating Mutations of RNF43 Confer Wnt Dependency in Pancreatic Ductal Adenocarcinoma. Proc. Natl. Acad. Sci. USA 2013, 110, 12649-12654. [CrossRef]

87. Manohar, M.; Fatima, I.; Saxena, R.; Chandra, V.; Sankhwar, P.L.; Dwivedi, A. (-)-Epigallocatechin-3-Gallate Induces Apoptosis in Human Endometrial Adenocarcinoma Cells via ROS Generation and P38 MAP Kinase Activation. J. Nutr. Biochem. 2013, 24, 940-947. [CrossRef] [PubMed]

88. What Is Endometrial Cancer? Available online: https://www.cancer.org/cancer/endometrial-cancer/about/what-isendometrial-cancer.html (accessed on 29 March 2021).

89. Creasman, W.; Odicino, F.; Maisonneuve, P.; Quinn, M.; Beller, U.; Benedet, J.; Heintz, A.; Ngan, H.; Pecorelli, S. Carcinoma of the Corpus Uteri. Int. J. Gynecol. Obstet. 2006, 95, S105-S143. [CrossRef]

90. Fatima, I.; Saxena, R.; Kharkwal, G.; Hussain, M.K.; Yadav, N.; Hajela, K.; Sankhwar, P.L.; Dwivedi, A. The Anti-Proliferative Effect of 2-[Piperidinoethoxyphenyl]-3-[4-Hydroxyphenyl]-2H-Benzo(b) Pyran Is Potentiated via Induction of Estrogen Receptor Beta and P21 in Human Endometrial Adenocarcinoma Cells. J. Steroid Biochem. Mol. Biol. 2013, 138, 123-131. [CrossRef]

91. Saegusa, M.; Hashimura, M.; Yoshida, T.; Okayasu, I. $\beta$-Catenin Mutations and Aberrant Nuclear Expression during Endometrial Tumorigenesis. Br. J. Cancer 2001, 84, 209-217. [CrossRef]

92. Friedenreich, C.M.; Biel, R.K.; Lau, D.C.W.; Csizmadi, I.; Courneya, K.S.; Magliocco, A.M.; Yasui, Y.; Cook, L.S. Case-Control Study of the Metabolic Syndrome and Metabolic Risk Factors for Endometrial Cancer. Cancer Epidemiol. Biomark. Prev. 2011, 20, 2384-2395. [CrossRef] 
93. La Vecchia, C.; Franceschi, S.; Decarli, A.; Gallus, G.; Tognoni, G. Risk Factors for Endometrial Cancer at Different Ages2. JNCI J. Natl. Cancer Inst. 1984, 73, 667-671. [CrossRef]

94. Kaaks, R.; Lukanova, A.; Kurzer, M.S. Obesity, Endogenous Hormones, and Endometrial Cancer Risk: A Synthetic Review. Cancer Epidemiol. Biomark. Prev. 2002, 11, 1531-1543.

95. Brinton, L.A.; Berman, M.L.; Mortel, R.; Twiggs, L.B.; Barrett, R.J.; Wilbanks, G.D.; Lannom, L.; Hoover, R.N. Reproductive, Menstrual, and Medical Risk Factors for Endometrial Cancer: Results from a Case-Control Study. Am. J. Obstet. Gynecol. 1992, 167, 1317-1325. [CrossRef]

96. Barman, S.; Srinivasan, K. Diabetes and Zinc Dyshomeostasis: Can Zinc Supplementation Mitigate Diabetic Complications? Crit. Rev. Food Sci. Nutr. 2020, 1-16. [CrossRef] [PubMed]

97. Barman, S.; Srinivasan, K. Attenuation of Oxidative Stress and Cardioprotective Effects of Zinc Supplementation in Experimental Diabetic Rats. Br. J. Nutr. 2017, 117, 335-350. [CrossRef] [PubMed]

98. Fatima, I.; Chandra, V.; Saxena, R.; Manohar, M.; Sanghani, Y.; Hajela, K.; Negi, M.P.S.; Sankhwar, P.L.; Jain, S.K.; Dwivedi, A. 2,3-Diaryl-2H-1-Benzopyran Derivatives Interfere with Classical and Non-Classical Estrogen Receptor Signaling Pathways, Inhibit Akt Activation and Induce Apoptosis in Human Endometrial Cancer Cells. Mol. Cell. Endocrinol. 2012, 348, 198-210. [CrossRef] [PubMed]

99. Mendivil, A.; Schuler, K.M.; Gehrig, P.A. Non-Endometrioid Adenocarcinoma of the Uterine Corpus: A Review of Selected Histological Subtypes. Cancer Control 2009, 16, 46-52. [CrossRef]

100. Liu, F.-S. Molecular Carcinogenesis of Endometrial Cancer. Taiwan. J. Obstet. Gynecol. 2007, 46, 26-32. [CrossRef]

101. Prat, J. Prognostic Parameters of Endometrial Carcinoma. Hum. Pathol. 2004, 35, 649-662. [CrossRef]

102. Kiewisz, J.; Wasniewski, T.; Kmiec, Z. Participation of WNT and $\beta$-Catenin in Physiological and Pathological Endometrial Changes: Association with Angiogenesis. Biomed. Res. Int. 2015, 2015, e854056. [CrossRef]

103. Wild, P.J.; Ikenberg, K.; Fuchs, T.J.; Rechsteiner, M.; Georgiev, S.; Fankhauser, N.; Noske, A.; Roessle, M.; Caduff, R.; Dellas, A.; et al. P53 Suppresses Type II Endometrial Carcinomas in Mice and Governs Endometrial Tumour Aggressiveness in Humans. EMBO Mol. Med. 2012, 4, 808-824. [CrossRef]

104. Olawaiye, A.B.; Boruta, D.M. Management of Women with Clear Cell Endometrial Cancer: A Society of Gynecologic Oncology (SGO) Review. Gynecol Oncol 2009, 113, 277-283. [CrossRef]

105. Samarnthai, N.; Hall, K.; Yeh, I.-T. Molecular Profiling of Endometrial Malignancies. Obstet. Gynecol. Int. 2010, 2010 , e162363. [CrossRef] [PubMed]

106. Matulonis, U.; Vergote, I.; Backes, F.; Martin, L.P.; McMeekin, S.; Birrer, M.; Campana, F.; Xu, Y.; Egile, C.; Ghamande, S. Phase II Study of the PI3K Inhibitor Pilaralisib (SAR245408; XL147) in Patients with Advanced or Recurrent Endometrial Carcinoma. Gynecol. Oncol. 2015, 136, 246-253. [CrossRef] [PubMed]

107. Kafshdooz, L.; Kafshdooz, T.; Tabrizi, A.D.; Ardabili, S.M.M.; Akbarzadeh, A.; Gharesouran, J.; Ghojazadeh, M.; Farajnia, S. Role of Exon 7 PTEN Gene in Endometrial Carcinoma. Asian Pac. J. Cancer Prev. 2015, 16, 4521-4524. [CrossRef]

108. Althubiti, M.A. Mutation Frequencies in Endometrial Cancer Patients of Different Ethnicities and Tumor Grades: An Analytical Study. Saudi J. Med. Med. Sci. 2019, 7, 16-21. [CrossRef] [PubMed]

109. Lheureux, S.; Braunstein, M.; Oza, A.M. Epithelial Ovarian Cancer: Evolution of Management in the Era of Precision Medicine. CA A Cancer J. Clin. 2019, 69, 280-304. [CrossRef]

110. Joehlin-Price, A.; Van Ziffle, J.; Hills, N.K.; Ladwig, N.; Rabban, J.T.; Garg, K. Molecularly Classified Uterine FIGO Grade 3 Endometrioid Carcinomas Show Distinctive Clinical Outcomes but Overlapping Morphologic Features. Am. J. Surg. Pathol. 2021, 45, 421-429. [CrossRef]

111. Hou, X.; Tan, Y.; Li, M.; Dey, S.K.; Das, S.K. Canonical Wnt Signaling Is Critical to Estrogen-Mediated Uterine Growth. Mol. Endocrinol. 2004, 18, 3035-3049. [CrossRef]

112. Katayama, S.; Ashizawa, K.; Fukuhara, T.; Hiroyasu, M.; Tsuzuki, Y.; Tatemoto, H.; Nakada, T.; Nagai, K. Differential Expression Patterns of Wnt and $\beta$-Catenin/TCF Target Genes in the Uterus of Immature Female Rats Exposed to $17 \alpha$-Ethynyl Estradiol. Toxicol. Sci. 2006, 91, 419-430. [CrossRef]

113. Tulac, S.; Overgaard, M.T.; Hamilton, A.E.; Jumbe, N.L.; Suchanek, E.; Giudice, L.C. Dickkopf-1, an Inhibitor of Wnt Signaling, Is Regulated by Progesterone in Human Endometrial Stromal Cells. J. Clin. Endocrinol. Metab. 2006, 91, 1453-1461. [CrossRef]

114. Bui, T.D.; Zhang, L.; Rees, M.C.P.; Bicknell, R.; Harris, A.L. Expression and Hormone Regulation of Wnt2, 3, 4, 5a, 7a, 7b and 10b in Normal Human Endometrium and Endometrial Carcinoma. Br. J. Cancer 1997, 75, 1131-1136. [CrossRef]

115. Liu, Y.; Patel, L.; Mills, G.B.; Lu, K.H.; Sood, A.K.; Ding, L.; Kucherlapati, R.; Mardis, E.R.; Levine, D.A.; Shmulevich, I.; et al. Clinical Significance of CTNNB1 Mutation and Wnt Pathway Activation in Endometrioid Endometrial Carcinoma. J. Natl. Cancer Inst. 2014, 106. [CrossRef] [PubMed]

116. Peng, C.; Zhang, X.; Wang, Y.; Li, L.; Wang, Q.; Zheng, J. Expression and Prognostic Significance of Wnt7a in Human Endometrial Carcinoma. Obstet. Gynecol. Int. 2012, 2012, e134962. [CrossRef] [PubMed]

117. Liu, Y.; Meng, F.; Xu, Y.; Yang, S.; Xiao, M.; Chen, X.; Lou, G. Overexpression of Wnt7a Is Associated with Tumor Progression and Unfavorable Prognosis in Endometrial Cancer. Int. J. Gynecol. Cancer 2013, 23. [CrossRef] [PubMed]

118. Coopes, A.; Henry, C.E.; Llamosas, E.; Ford, C.E. An Update of Wnt Signalling in Endometrial Cancer and Its Potential as a Therapeutic Target. Endocr. Relat. Cancer 2018, 25, R647-R662. [CrossRef] 
119. Chen, H.; Wang, Y.; Xue, F. Expression and the Clinical Significance of Wnt10a and Wnt10b in Endometrial Cancer Are Associated with the Wnt/ $\beta$-Catenin Pathway. Oncol. Rep. 2013, 29, 507-514. [CrossRef]

120. Li, P.; Liu, W.; Xu, Q.; Wang, C. Clinical Significance and Biological Role of Wnt10a in Ovarian Cancer. Oncol. Lett. 2017, 14, 6611-6617. [CrossRef] [PubMed]

121. Van der Zee, M.; Jia, Y.; Wang, Y.; Heijmans-Antonissen, C.; Ewing, P.C.; Franken, P.; DeMayo, F.J.; Lydon, J.P.; Burger, C.W.; Fodde, R.; et al. Alterations in Wnt- $\beta$-Catenin and Pten Signalling Play Distinct Roles in Endometrial Cancer Initiation and Progression. J. Pathol. 2013, 230, 48-58. [CrossRef]

122. Ikeda, T.; Yoshinaga, K.; Semba, S.; Kondo, E.; Ohmori, H.; Horii, A. Mutational Analysis of the CTNNB1 (Beta-Catenin) Gene in Human Endometrial Cancer: Frequent Mutations at Codon 34 That Cause Nuclear Accumulation. Oncol. Rep. 2000, 7, 323-329. [CrossRef]

123. Byron, S.A.; Gartside, M.; Powell, M.A.; Wellens, C.L.; Gao, F.; Mutch, D.G.; Goodfellow, P.J.; Pollock, P.M. FGFR2 Point Mutations in 466 Endometrioid Endometrial Tumors: Relationship with MSI, KRAS, PIK3CA, CTNNB1 Mutations and Clinicopathological Features. PLoS ONE 2012, 7, e30801. [CrossRef]

124. Wright, K.; Wilson, P.; Morland, S.; Campbell, I.; Walsh, M.; Hurst, T.; Ward, B.; Cummings, M.; Chenevix-Trench, G. $\beta$-Catenin Mutation and Expression Analysis in Ovarian Cancer: Exon 3 Mutations and Nuclear Translocation in 16\% of Endometrioid Tumours. Int. J. Cancer 1999, 82, 625-629. [CrossRef]

125. Aust, D.E.; Terdiman, J.P.; Willenbucher, R.F.; Chang, C.G.; Molinaro-Clark, A.; Baretton, G.B.; Loehrs, U.; Waldman, F.M. The APC/ $\beta$-Catenin Pathway in Ulcerative Colitis-Related Colorectal Carcinomas. Cancer 2002, 94, 1421-1427. [CrossRef]

126. Abraham, S.C.; Reynolds, C.; Lee, J.-H.; Montgomery, E.A.; Baisden, B.L.; Krasinskas, A.M.; Wu, T.-T. Fibromatosis of the Breast and Mutations Involving the APC/ $\beta$-Catenin Pathway. Hum. Pathol. 2002, 33, 39-46. [CrossRef]

127. Ebert, M.P.A.; Fei, G.; Kahmann, S.; Müller, O.; Yu, J.; Sung, J.J.Y.; Malfertheiner, P. Increased $\beta$-Catenin MRNA Levels and Mutational Alterations of the APC and $\beta$-Catenin Gene Are Present in Intestinal-Type Gastric Cancer. Carcinogenesis 2002, 23, 87-91. [CrossRef] [PubMed]

128. Mirabelli-Primdahl, L.; Gryfe, R.; Kim, H.; Millar, A.; Luceri, C.; Dale, D.; Holowaty, E.; Bapat, B.; Gallinger, S.; Redston, M. $\beta$-Catenin Mutations Are Specific for Colorectal Carcinomas with Microsatellite Instability but Occur in Endometrial Carcinomas Irrespective of Mutator Pathway. Cancer Res. 1999, 59, 3346-3351. [PubMed]

129. Moreno-Bueno, G.; Hardisson, D.; Sánchez, C.; Sarrió, D.; Cassia, R.; García-Rostán, G.; Prat, J.; Guo, M.; Herman, J.G.; Matías-Guiu, X.; et al. Abnormalities of the APC/ $\beta$-Catenin Pathway in Endometrial Cancer. Oncogene 2002, 21, 7981-7990. [CrossRef]

130. Travaglino, A.; Raffone, A.; Saccone, G.; De Luca, C.; Mollo, A.; Mascolo, M.; De Placido, G.; Insabato, L.; Zullo, F. Immunohistochemical Nuclear Expression of $\beta$-Catenin as a Surrogate of CTNNB1 Exon 3 Mutation in Endometrial Cancer. Am. J. Clin. Pathol. 2019, 151, 529-538. [CrossRef] [PubMed]

131. De Leo, A.; de Biase, D.; Lenzi, J.; Barbero, G.; Turchetti, D.; Grillini, M.; Ravegnini, G.; Angelini, S.; Zamagni, C.; Coluccelli, S.; et al. ARID1A and CTNNB1/ $\beta$-Catenin Molecular Status Affects the Clinicopathologic Features and Prognosis of Endometrial Carcinoma: Implications for an Improved Surrogate Molecular Classification. Cancers 2021, 13, 950. [CrossRef] [PubMed]

132. Kim, G.; Kurnit, K.C.; Djordjevic, B.; Singh, C.; Munsell, M.F.; Wang, W.-L.; Lazar, A.J.; Zhang, W.; Broaddus, R. Nuclear $\beta$-Catenin Localization and Mutation of the CTNNB1 Gene: A Context-Dependent Association. Mod. Pathol. 2018, 31, 1553-1559. [CrossRef] [PubMed]

133. Shelton, D.; Goodheart, M. Wnt/ß-Catenin/Lef-1 Signaling in the Uterus and Its Implications in Uterine Gland Formation and Cancer Development. Proc. Obstet. Gynecol. 2011, 2, 1-11. [CrossRef]

134. Shelton, D.N.; Fornalik, H.; Neff, T.; Park, S.Y.; Bender, D.; DeGeest, K.; Liu, X.; Xie, W.; Meyerholz, D.K.; Engelhardt, J.F.; et al. The Role of LEF1 in Endometrial Gland Formation and Carcinogenesis. PLoS ONE 2012, 7, e40312. [CrossRef]

135. Hospices Civils de Lyon. Predictive Value of Progastrin Titer at Diagnosis and of Progastrin Kinetics During Treatment in Cancer Patients; Hospices Civils de Lyon: Lyon, France, 2018. Available online: Clinicaltrials.gov (accessed on 10 May 2021).

136. Oza, A.M.; Elit, L.; Tsao, M.-S.; Kamel-Reid, S.; Biagi, J.; Provencher, D.M.; Gotlieb, W.H.; Hoskins, P.J.; Ghatage, P.; Tonkin, K.S.; et al. Phase II Study of Temsirolimus in Women with Recurrent or Metastatic Endometrial Cancer: A Trial of the NCIC Clinical Trials Group. J. Clin. Oncol. 2011, 29, 3278-3285. [CrossRef]

137. Aghajanian, C.; Sill, M.W.; Darcy, K.M.; Greer, B.; McMeekin, D.S.; Rose, P.G.; Rotmensch, J.; Barnes, M.N.; Hanjani, P.; Leslie, K.K. Phase II Trial of Bevacizumab in Recurrent or Persistent Endometrial Cancer: A Gynecologic Oncology Group Study. J. Clin. Oncol. 2011, 29, 2259-2265. [CrossRef]

138. Barker, N.; Clevers, H. Mining the Wnt Pathway for Cancer Therapeutics. Nat. Rev. Drug Discov. 2006, 5, 997-1014. [CrossRef] [PubMed]

139. Kim, J.-S.; Crooks, H.; Foxworth, A.; Waldman, T. Proof-of-Principle: Oncogenic $\beta$-Catenin Is a Valid Molecular Target for the Development of Pharmacological Inhibitors 1 Supported by NIH Grants K01 CA87828, R55 CA95736, and R01 CA095736 and the Lombardi Cancer Center Support Grant P30 CA51008. T.W. Is a V Foundation Scholar and the Recipient of a Career Development Award from the American Society of Clinical Oncology. 1. Mol. Cancer 2002, 1, 1355-1359.

140. Yahata, T.; Fujita, K.; Aoki, Y.; Tanaka, K. Long-Term Conservative Therapy for Endometrial Adenocarcinoma in Young Women. Hum. Reprod. 2006, 21, 1070-1075. [CrossRef] [PubMed] 
141. M.D. Anderson Cancer Center. A Phase II Study of the Levonorgestrel Intrauterine Device (Mirena) to Treat Complex Atypical Hyperplasia and Grade 1 Endometrioid Endometrial Carcinoma; MD Anderson Cancer Center: Austin, MN, USA, 2019. Available online: Clinicaltrials.gov (accessed on 10 May 2021).

142. Westin, S.N.; Fellman, B.; Sun, C.C.; Broaddus, R.R.; Woodall, M.L.; Pal, N.; Urbauer, D.L.; Ramondetta, L.M.; Schmeler, K.M.; Soliman, P.T.; et al. Prospective Phase II Trial of Levonorgestrel Intrauterine Device: Nonsurgical Approach for Complex Atypical Hyperplasia and Early-Stage Endometrial Cancer. Am. J. Obstet. Gynecol. 2021, 224, 191.e1-191.e15. [CrossRef] [PubMed]

143. Leap Therapeutics, Inc. A Phase 2 Study Evaluating the Efficacy and Safety of DKN-01 as a Monotherapy or in Combination with Paclitaxel in Patients with Recurrent Epithelial Endometrial, Epithelial Ovarian Cancer, or Carcinosarcoma; Leap Therapeutics, Inc.: Cambridge, MA, USA, 2020. Available online: Clinicaltrials.gov (accessed on 10 May 2021).

144. Madan, B.; Ke, Z.; Harmston, N.; Ho, S.Y.; Frois, A.O.; Alam, J.; Jeyaraj, D.A.; Pendharkar, V.; Ghosh, K.; Virshup, I.H.; et al. Wnt Addiction of Genetically Defined Cancers Reversed by PORCN Inhibition. Oncogene 2016, 35, 2197-2207. [CrossRef] [PubMed]

145. Nygaard, R.; Yu, J.; Kim, J.; Ross, D.R.; Parisi, G.; Clarke, O.B.; Virshup, D.M.; Mancia, F. Structural Basis of WLS/Evi-Mediated Wnt Transport and Secretion. Cell 2021, 184, 194-206.e14. [CrossRef] [PubMed]

146. Boone, J.D.; Arend, R.C.; Johnston, B.E.; Cooper, S.J.; Gilchrist, S.A.; Oelschlager, D.K.; Grizzle, W.E.; McGwin, G.; Gangrade, A.; Straughn, J.M.; et al. Targeting the Wnt/ $\beta$-Catenin Pathway in Primary Ovarian Cancer with the Porcupine Inhibitor WNT974. Lab. Investig. 2016, 96, 249-259. [CrossRef] [PubMed]

147. EDDC (Experimental Drug Development Centre). A*STAR Research Entities. In A Phase $1 A / B$ Study to Evaluate the Safety and Tolerability of ETC-1922159 in Advanced Solid Tumours; Experimental Drug Development Centre: Singapore, 2020. Available online: Clinicaltrials.gov (accessed on 10 May 2021).

148. Kim, M.J.; Huang, Y.; Park, J.-I. Targeting Wnt Signaling for Gastrointestinal Cancer Therapy: Present and Evolving Views. Cancers 2020, 12, 3638. [CrossRef]

149. Le, P.N.; McDermott, J.D.; Jimeno, A. Targeting the Wnt Pathway in Human Cancers: Therapeutic Targeting with a Focus on OMP-54F28. Pharmacol. Ther. 2015, 146, 1-11. [CrossRef]

150. Fischer, M.M.; Cancilla, B.; Yeung, V.P.; Cattaruzza, F.; Chartier, C.; Murriel, C.L.; Cain, J.; Tam, R.; Cheng, C.-Y.; Evans, J.W.; et al. WNT Antagonists Exhibit Unique Combinatorial Antitumor Activity with Taxanes by Potentiating Mitotic Cell Death. Sci. Adv. 2017, 3, e1700090. [CrossRef] [PubMed]

151. Zhan, T.; Rindtorff, N.; Boutros, M. Wnt Signaling in Cancer. Oncogene 2017, 36, 1461-1473. [CrossRef] [PubMed]

152. Jimeno, A.; Gordon, M.S.; Chugh, R.; Messersmith, W.A.; Mendelson, D.S.; Dupont, J.; Stagg, R.J.; Kapoun, A.; Xu, L.; Brachmann, R.K.; et al. A First-in-Human Phase 1 Study of Anticancer Stem Cell Agent OMP-54F28 (FZD8-Fc), Decoy Receptor for WNT Ligands, in Patients with Advanced Solid Tumors. JCO 2014, 32, 2505. [CrossRef]

153. Jimeno, A.; Gordon, M.; Chugh, R.; Messersmith, W.; Mendelson, D.; Dupont, J.; Stagg, R.; Kapoun, A.M.; Xu, L.; Uttamsingh, S.; et al. A First-in-Human Phase I Study of the Anticancer Stem Cell Agent Ipafricept (OMP-54F28), a Decoy Receptor for Wnt Ligands, in Patients with Advanced Solid Tumors. Clin. Cancer Res. 2017, 23, 7490-7497. [CrossRef]

154. Arend, R.C.; Londoño-Joshi, A.I.; Samant, R.S.; Li, Y.; Conner, M.; Hidalgo, B.; Alvarez, R.D.; Landen, C.N.; Straughn, J.M.; Buchsbaum, D.J. Inhibition of Wnt/ $\beta$-Catenin Pathway by Niclosamide: A Therapeutic Target for Ovarian Cancer. Gynecol. Oncol. 2014, 134, 112-120. [CrossRef] [PubMed]

155. Wieland, A.; Trageser, D.; Gogolok, S.; Reinartz, R.; Höfer, H.; Keller, M.; Leinhaas, A.; Schelle, R.; Normann, S.; Klaas, L.; et al. Anticancer Effects of Niclosamide in Human Glioblastoma. Clin. Cancer Res. 2013, 19, 4124-4136. [CrossRef]

156. Lu, W.; Lin, C.; Roberts, M.J.; Waud, W.R.; Piazza, G.A.; Li, Y. Niclosamide Suppresses Cancer Cell Growth By Inducing Wnt Co-Receptor LRP6 Degradation and Inhibiting the Wnt/ $\beta$-Catenin Pathway. PLoS ONE 2011, 6, e29290. [CrossRef]

157. Chen, M.; Wang, J.; Lu, J.; Bond, M.C.; Ren, X.-R.; Lyerly, H.K.; Barak, L.S.; Chen, W. The Anti-Helminthic Niclosamide Inhibits Wnt/Frizzled1 Signaling. Biochemistry 2009, 48, 10267-10274. [CrossRef]

158. Osada, T.; Chen, M.; Yang, X.Y.; Spasojevic, I.; Vandeusen, J.B.; Hsu, D.; Clary, B.M.; Clay, T.M.; Chen, W.; Morse, M.A.; et al. Antihelminth Compound Niclosamide Downregulates Wnt Signaling and Elicits Antitumor Responses in Tumors with Activating APC Mutations. Cancer Res. 2011, 71, 4172-4182. [CrossRef]

159. King, M.L.; Lindberg, M.E.; Stodden, G.R.; Okuda, H.; Ebers, S.D.; Johnson, A.; Montag, A.; Lengyel, E.; MacLean Ii, J.A.; Hayashi, K. WNT7A/ $\beta$-Catenin Signaling Induces FGF1 and Influences Sensitivity to Niclosamide in Ovarian Cancer. Oncogene 2015, 34, 3452-3462. [CrossRef] [PubMed]

160. Nguyen, C.; Ma, H.; Kim, D.H.; Jeong, K.W.; Eguchi, M.; Moon, R.T.; Teo, J.L.; Kim, H.Y.; Moon, S.H. A Small Molecule Inhibitor of -Catenin/CREB-Binding Protein Transcription. Proc. Natl. Acad. Sci. USA 2004, 101, 12682-12687. [CrossRef]

161. Rebel, V.I.; Kung, A.L.; Tanner, E.A.; Yang, H.; Bronson, R.T.; Livingston, D.M. Distinct Roles for CREB-Binding Protein and P300 in Hematopoietic Stem Cell Self-Renewal. Proc. Natl. Acad. Sci. USA 2002, 99, 14789-14794. [CrossRef] [PubMed]

162. McWilliams, R.R.; Ko, A.H.; Chiorean, E.G.; Kwak, E.L.; Lenz, H.-J.; Nadler, P.I.; Wood, D.L.; Fujimori, M.; Morita, K.; Inada, T.; et al. A Phase Ib Dose-Escalation Study of PRI-724, a CBP/Beta-Catenin Modulator, plus Gemcitabine (GEM) in Patients with Advanced Pancreatic Adenocarcinoma (APC) as Second-Line Therapy after FOLFIRINOX or FOLFOX. JCO 2015, 33 , e15270. [CrossRef] 
163. University of Southern California. PRIMIER*: Randomized Phase II Trial of MFOLFOX6/Bevacizumab with or without PRI-724 as First Line Treatment for Metastatic Colorectal Cancer; University of Southern California: Los Angeles, CA, USA, 2017. Available online: Clinicaltrials.gov (accessed on 25 January 2021).

164. Gupta, P.B.; Onder, T.T.; Jiang, G.; Tao, K.; Kuperwasser, C.; Weinberg, R.A.; Lander, E.S. Identification of Selective Inhibitors of Cancer Stem Cells by High-Throughput Screening. Cell 2009, 138, 645-659. [CrossRef] [PubMed]

165. Kusunoki, S.; Kato, K.; Tabu, K.; Inagaki, T.; Okabe, H.; Kaneda, H.; Suga, S.; Terao, Y.; Taga, T.; Takeda, S. The Inhibitory Effect of Salinomycin on the Proliferation, Migration and Invasion of Human Endometrial Cancer Stem-like Cells. Gynecol. Oncol. 2013, 129, 598-605. [CrossRef] [PubMed]

166. Srinivasan, K. Antimutagenic and Cancer Preventive Potential of Culinary Spices and Their Bioactive Compounds. PharmaNutrition 2017, 5, 89-102. [CrossRef]

167. Kanai, M. Therapeutic Applications of Curcumin for Patients with Pancreatic Cancer. World J. Gastroenterol. 2014, $20,9384-9391$. [CrossRef] [PubMed]

168. Gupta, S.C.; Patchva, S.; Aggarwal, B.B. Therapeutic Roles of Curcumin: Lessons Learned from Clinical Trials. AAPS J. 2013, 15, 195-218. [CrossRef]

169. Feng, W.; Yang, C.X.; Zhang, L.; Fang, Y.; Yan, M. Curcumin Promotes the Apoptosis of Human Endometrial Carcinoma Cells by Downregulating the Expression of Androgen Receptor through Wnt Signal Pathway. Eur. J. Gynaecol. Oncol. 2014, 35, 718-723.

170. Martens-Uzunova, E.S.; Olvedy, M.; Jenster, G. Beyond MicroRNA-Novel RNAs Derived from Small Non-Coding RNA and Their Implication in Cancer. Cancer Lett. 2013, 340, 201-211. [CrossRef]

171. Wang, Z.-M.; Wan, X.-H.; Sang, G.-Y.; Zhao, J.-D.; Zhu, Q.-Y.; Wang, D.-M. MiR-15a-5p Suppresses Endometrial Cancer Cell Growth via Wnt/ $\beta$-Catenin Signaling Pathway by Inhibiting WNT3A. Eur. Rev. Med. Pharmacol. Sci. 2017, 21, 4810-4818. [PubMed]

172. Qin, X.; Yan, L.; Zhao, X.; Li, C.; Fu, Y. MicroRNA-21 Overexpression Contributes to Cell Proliferation by Targeting PTEN in Endometrioid Endometrial Cancer. Oncol. Lett. 2012, 4, 1290-1296. [CrossRef] [PubMed]

173. Yu, Y.; Kanwar, S.S.; Patel, B.B.; Oh, P.-S.; Nautiyal, J.; Sarkar, F.H.; Majumdar, A.P.N. MicroRNA-21 Induces Stemness by Downregulating Transforming Growth Factor Beta Receptor 2 (TGF $\beta R 2$ ) in Colon Cancer Cells. Carcinogenesis 2012, 33, 68-76. [CrossRef] [PubMed]

174. Kawakita, A.; Yanamoto, S.; Yamada, S.; Naruse, T.; Takahashi, H.; Kawasaki, G.; Umeda, M. MicroRNA-21 Promotes Oral Cancer Invasion via the Wnt/ $\beta$-Catenin Pathway by Targeting DKK2. Pathol. Oncol. Res. 2014, 20, 253-261. [CrossRef]

175. Yan, J.; Liu, T.; Zhou, X.; Dang, Y.; Yin, C.; Zhang, G. FZD6, Targeted by MiR-21, Represses Gastric Cancer Cell Proliferation and Migration via Activating Non-Canonical Wnt Pathway. Am. J. Transl. Res. 2016, 8, 2354-2364. [PubMed]

176. Huang, X.; Zhong, R.; He, X.; Deng, Q.; Peng, X.; Li, J.; Luo, X. Investigations on the Mechanism of Progesterone in Inhibiting Endometrial Cancer Cell Cycle and Viability via Regulation of Long Noncoding RNA NEAT1/MicroRNA-146b-5p Mediated Wnt/ $\beta$-Catenin Signaling. IUBMB Life 2019, 71, 223-234. [CrossRef]

177. Snowdon, J.; Zhang, X.; Childs, T.; Tron, V.A.; Feilotter, H. The MicroRNA-200 Family Is Upregulated in Endometrial Carcinoma. PLoS ONE 2011, 6, e22828. [CrossRef]

178. Lee, J.-W.; Park, Y.-A.; Choi, J.-J.; Lee, Y.Y.; Kim, C.-J.; Choi, C.; Kim, T.-J.; Lee, N.W.; Kim, B.-G.; Bae, D.-S. The Expression of the MiRNA-200 Family in Endometrial Endometrioid Carcinoma. Gynecol. Oncol. 2011, 120, 56-62. [CrossRef]

179. Su, J.; Zhang, A.; Shi, Z.; Ma, F.; Pu, P.; Wang, T.; Zhang, J.; Kang, C.; Zhang, Q. MicroRNA-200a Suppresses the Wnt/ $\beta-C a t e n i n$ Signaling Pathway by Interacting with $\beta$-Catenin. Int. J. Oncol. 2012, 40, 1162-1170. [CrossRef]

180. Saydam, O.; Shen, Y.; Würdinger, T.; Senol, O.; Boke, E.; James, M.F.; Tannous, B.A.; Stemmer-Rachamimov, A.O.; Yi, M.; Stephens, R.M.; et al. Downregulated MicroRNA-200a in Meningiomas Promotes Tumor Growth by Reducing E-Cadherin and Activating the Wnt/ $\beta$-Catenin Signaling Pathway. Mol. Cell. Biol. 2009, 29, 5923-5940. [CrossRef] [PubMed]

181. Cong, N.; Du, P.; Zhang, A.; Shen, F.; Su, J.; Pu, P.; Wang, T.; Zjang, J.; Kang, C.; Zhang, Q. Downregulated MicroRNA-200a Promotes EMT and Tumor Growth through the Wnt/ $\beta$-Catenin Pathway by Targeting the E-Cadherin Repressors ZEB1/ZEB2 in Gastric Adenocarcinoma. Oncol. Rep. 2013, 29, 1579-1587. [CrossRef] [PubMed]

182. Lachej, N.; Jonušienė, V.; Mažeikè, A.; Sasnauskienė, A.; Dabkevičienė, D.; Šimienè, J.; Sužiedèlis, K.; Didžiapetrienė, J. Changes in the Expression of Notch and Wnt Signalling Molecules in Human Endometrial Cancer. Acta Med. Litu. 2019, 26, 181-190. [CrossRef] [PubMed]

183. Kasoha, M.; Dernektsi, C.; Seibold, A.; Bohle, R.M.; Takacs, Z.; Ioan-Iulian, I.; Solomayer, E.-F.; Juhasz-Böss, I. Crosstalk of Estrogen Receptors and Wnt/ $\beta$-Catenin Signaling in Endometrial Cancer. J. Cancer Res. Clin. Oncol. 2020, 146, 315-327. [CrossRef] [PubMed]

184. Martin-Orozco, E.; Sanchez-Fernandez, A.; Ortiz-Parra, I.; Ayala-San Nicolas, M. WNT Signaling in Tumors: The Way to Evade Drugs and Immunity. Front. Immunol. 2019, 10, 2854. [CrossRef]

185. Lu, H.; Ju, D.-D.; Yang, G.-D.; Zhu, L.-Y.; Yang, X.-M.; Li, J.; Song, W.-W.; Wang, J.-H.; Zhang, C.-C.; Zhang, Z.-G.; et al. Targeting Cancer Stem Cell Signature Gene SMOC-2 Overcomes Chemoresistance and Inhibits Cell Proliferation of Endometrial Carcinoma. EBioMedicine 2019, 40, 276-289. [CrossRef]

186. Patel, S.; Alam, A.; Pant, R.; Chattopadhyay, S. Wnt Signaling and Its Significance Within the Tumor Microenvironment: Novel Therapeutic Insights. Front. Immunol. 2019, 10, 2872. [CrossRef] [PubMed] 
187. Wang, B.; Tian, T.; Kalland, K.-H.; Ke, X.; Qu, Y. Targeting Wnt/ $\beta$-Catenin Signaling for Cancer Immunotherapy. Trends Pharm. Sci. 2018, 39, 648-658. [CrossRef]

188. Huang, T.; Li, F.; Cheng, X.; Wang, J.; Zhang, W.; Zhang, B.; Tang, Y.; Li, Q.; Zhou, C.; Tu, S. Wnt Inhibition Sensitizes PDL1 Blockade Therapy by Overcoming Bone Marrow-Derived Myofibroblasts-Mediated Immune Resistance in Tumors. Front. Immunol. 2021, 12, 619209. [CrossRef]

189. Aripaka, K.; Gudey, S.K.; Zang, G.; Schmidt, A.; Åhrling, S.S.; Österman, L.; Bergh, A.; von Hofsten, J.; Landström, M. TRAF6 Function as a Novel Co-Regulator of Wnt3a Target Genes in Prostate Cancer. EBioMedicine 2019, 45, 192-207. [CrossRef]

190. Turcios, L.; Chacon, E.; Garcia, C.; Eman, P.; Cornea, V.; Jiang, J.; Spear, B.; Liu, C.; Watt, D.S.; Marti, F.; et al. Autophagic Flux Modulation by Wnt/ $\beta$-Catenin Pathway Inhibition in Hepatocellular Carcinoma. PLoS ONE 2019, 14, e0212538. [CrossRef] [PubMed]

191. Pérez-Plasencia, C.; López-Urrutia, E.; García-Castillo, V.; Trujano-Camacho, S.; López-Camarillo, C.; Campos-Parra, A.D. Interplay between Autophagy and Wnt/ $\beta$-Catenin Signaling in Cancer: Therapeutic Potential Through Drug Repositioning. Front. Oncol. 2020, 10, 1037. [CrossRef] [PubMed]

192. Jung, Y.-S.; Park, J.-I. Wnt Signaling in Cancer: Therapeutic Targeting of Wnt Signaling beyond $\beta$-Catenin and the Destruction Complex. Exp. Mol. Med. 2020, 52, 183-191. [CrossRef]

193. Goad, J.; Ko, Y.-A.; Kumar, M.; Jamaluddin, M.F.B.; Tanwar, P.S. Oestrogen Fuels the Growth of Endometrial Hyperplastic Lesions Initiated by Overactive Wnt/ $\beta$-Catenin Signalling. Carcinogenesis 2018, 39, 1105-1116. [CrossRef] [PubMed]

194. Feng, M.; Zhang, T.; Ma, H. Progesterone Ameliorates the Endometrial Polyp by Modulating the Signaling Pathway of Wnt and $\beta$-Catenin via Regulating the Expression of H19 and MiR-152. J. Cell. Biochem. 2019, 120, 10164-10174. [CrossRef] 